
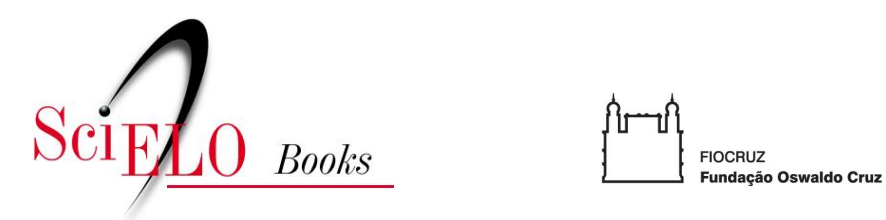

ipea

\title{
A coordenação federativa do sistema público de saúde no Brasil
}

\author{
Luciana Dias de Lima
}

\section{SciELO Books / SciELO Livros / SciELO Libros}

LIMA, LD. A coordenação federativa do sistema público de saúde no Brasil. In FUNDAÇÃO OSWALDO CRUZ. A saúde no Brasil em 2030 - prospecção estratégica do sistema de saúde brasileiro: organização e gestão do sistema de saúde [online]. Rio de Janeiro: Fiocruz/Ipea/Ministério da Saúde/Secretaria de Assuntos Estratégicos da Presidência da República, 2013. Vol. 3. pp. 73-139. ISBN 978-85-8110-017-3. Available from SciELO Books <http://books.scielo.org>.

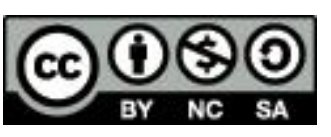

All the contents of this chapter, except where otherwise noted, is licensed under a Creative Commons Attribution-Non Commercial-ShareAlike 3.0 Unported.

Todo o conteúdo deste capítulo, exceto quando houver ressalva, é publicado sob a licença Creative Commons Atribuição Uso Não Comercial - Partilha nos Mesmos Termos 3.0 Não adaptada.

Todo el contenido de este capítulo, excepto donde se indique lo contrario, está bajo licencia de la licencia Creative Commons Reconocimento-NoComercial-CompartirIgual 3.0 Unported. 


\section{A Coordenação Federativa do Sistema Público de Saúde no Brasil}




\title{
A COORDENAÇÃO FEDERATIVA DO SISTEMA PÚBLICO DE SAÚDE NO BRASIL
}

\author{
Luciana Dias de Lima
}

\section{1 | INTRODUÇÃO}

Descentralização e regionalização são princípios complementares que norteiam a organização político-territorial do Sistema Único de Saúde (SUS).

Tal como concebida na Constituição Federal de 1988 (CF 88) e na Lei Orgânica da Saúde (Brasil, 1988 e 1990a), a descentralização, associada ao comando único em cada esfera de governo ${ }^{1}$, redefine responsabilidades entre os entes, reforçando a importância dos executivos municipais e estaduais na política de saúde 2 . O fortalecimento desses governos se justifica como forma de promover a democratização e incorporar novos atores sociais (GERSCHMAN, 1995) de modo coerente com o desenho federativo brasileiro (AFFONSO e SILVA, 1995), e melhorar a eficiência, a efetividade e os mecanismos de accountability nas políticas públicas (MÉDICI, 1994).

Entretanto, os fatores que determinam os problemas de saúde não se restringem aos limites político-administrativos das esferas subnacionais no Brasil. Agrega-se o fato de que a maior parte dos municípios e muitos estados não possuem condições para prover de forma autônoma as ações e serviços necessários à sua população, apresentando recursos (financeiros, materiais e humanos) muito

1 O comando único (ou direção única) em cada esfera de governo é a tentativa de garantir, na gestão da política de saúde, a observância de um princípio comum a todo sistema federativo: a autonomia relativa dos governos na elaboração de suas políticas próprias. Assim, no âmbito nacional, a gestão do sistema deve ser realizada de forma coerente com as políticas elaboradas pelo Ministério da Saúde, no âmbito estadual, com as políticas elaboradas pelas secretarias estaduais, e, no âmbito municipal, pelas secretarias municipais de saúde.

2 Mesmo enfatizando a descentralização como uma diretriz para organização do SUS (Art. 198), a CF 88 considera a saúde "direito de todos e dever do Estado" (Art.196), o "cuidar da saúde" uma competência comum (Art. 23) dos entes federados e a "defesa da saúde" objeto de legislação concorrente (Art. 24) entre União, estados e Distrito Federal (BRASIL, 1988). Posteriormente, a Lei Orgânica da Saúde e uma série de atos normativos editados ao longo dos anos 1990 e 2000 possibilitaram o melhor delineamento de funções entre os entes governamentais na política de saúde. 
diferenciados entre si. Frente à concentração geográfica de serviços e às disparidades de porte populacional e condições político-institucionais entre os entes municipais e estaduais, a interdependência entre os governos é bastante significativa no SUS (MENDES, 1999; CAMPOS, 2006; SANTOS e ANDRADE, 2011), sendo necessário "transcender suas fronteiras" sem, contudo, desconsiderá-las, para se planejar e conformar uma rede de atenção integral à saúde no território³.

Ressalta-se que as regiões geográficas na saúde são normalmente planejadas de modo a conter uma dada densidade tecnológica e autossuficiência de ações e serviços, capaz de responder às necessidades de uma população. Diversas variáveis, gerais e específicas do setor, influenciam a capacidade de resposta do sistema de saúde em âmbito regional, entre elas: o perfil demográfico, sócioeconômico e epidemiológico das populações; a distribuição e disponibilidade espacial de equipamentos, insumos e tecnologias, formação e qualificação profissional; as dinâmicas territoriais (políticas, econômicas e sociais) de determinadas regiões, como aquelas relacionadas às áreas metropolitanas e fronteiriças e à Amazônia Legal; as estruturas, meios e agentes que exercem influência sobre o território.

A regionalização, portanto, traduz-se como um processo político mais amplo, condicionado pelas relações estabelecidas entre diferentes atores nos espaços regionais: entes governamentais, organizações públicas e privadas, cidadãos (FLEURY e OUVERNEY, 2007; VIANA et al., 2008; VIANA, LIMA e FERREIRA, 2010). Inclui, ainda, o desenvolvimento de estratégias e instrumentos de planejamento, integração, gestão, regulação e financiamento de uma rede regionalizada de ações e serviços de saúde (MENDES, 2009 e 2010; KUSCHNIR e CHORNY, 2010).

Além disso, a regionalização pressupõe a diversidade de aspectos que distinguem o território brasileiro e que devem ser levados em consideração no planejamentodepolíticaspúblicas,buscandogarantira adequaçãoecomplementaridade das regiões (VIANA et al., 2008), mas também uma inserção diferenciada da saúde nos processos de desenvolvimento, produção e incorporação tecnológica (GADELHA, MACHADO, LIMA e BAPTISTA, 2009).

Considera-se que a organização político-territorial de sistemas de saúde guarda especificidades em países federativos (PIERSON e LIEBFRIED, 1995). Sob regimes democráticos, o desenho institucional das federações garante a repartição do poder do Estado em múltiplos centros, de modo que diferentes esferas de governo possam participar do processo político e defender seus interesses e direitos originários (ELAZAR, 1987; LIJPHART, 2003). Dependendo do arranjo federativo adotado e da

3 Entende-se por rede de atenção integral à saúde o conjunto de unidades, de diferentes funções e perfis de atendimento, que operam de modo ordenado e articulado. A concepção de rede de saúde expressa em documento da Organização Pan-americana de Saúde (OPAS, 2008) e em portaria recentemente publicada pelo Ministério da Saúde (BRASIL, 2010) pressupõe o território como um de seus atributos, essencial para sua organização e funcionamento. 
trajetória histórica da política de saúde nesses países, a implantação de sistemas nacionais universais pode exigir um processo longo e permanente de negociação entre autoridades políticas dotadas de legitimidade, visões e projetos distintos, envolvendo relações de cooperação e competição, acordos, vetos e decisões conjuntas entre governos.

Por outro lado, nesses países, a natureza sistêmica dos processos de descentralização e regionalização induz a mudanças na distribuição do poder e nas relações interinstitucionais estabelecidas na política de saúde, o que requer o fortalecimento de mecanismos de coordenação.

A coordenação federativa é concebida nesse trabalho como formas de articulação (interação, compartilhamento e decisão conjunta), que resultam na instauração de parcerias aprovadas pelas diferentes esferas governamentais, em diferentes setores das políticas públicas (ABRUCIO, 2005). Ela é um elemento-chave para se buscar o equilíbrio entre autonomia e interdependência dos governos e para amenizar os conflitos existentes entre eles, favorecendo um modus operandi cooperativo ${ }^{4}$. Diversos mecanismos possibilitam a coordenação de políticas: instrumentos legais e normativos voltados para a distribuição de funções e competências gestoras; instâncias federativas e mecanismos de negociação intergovernamental; funcionamento regular das instituições representativas; papel coordenador e/ou indutor do governo federal/ estadual.

Para Viana, Lima e Oliveira (2002), a coordenação de políticas de saúde em cenário federalista também necessita da emergência de estruturas dedicadas à construção da relação centro/periferia, do reforço de burocracias eficientes nas diferentes esferas de governo, da atuação de gestores intergovernamentais e do desenvolvimento de instrumentos de diplomacia que favoreçam o entendimento e a cooperação intergovernamental.

Reconhecendo a complexidade do modelo preconizado no SUS, este capítulo tem como objetivo analisar os mecanismos de coordenação federativa implementados na política de saúde de 1990 a 2010, destacando-se limites e desafios, bem como propostas para seu aprimoramento nas próximas duas décadas.

Em termos metodológicos o trabalho ancora-se no referencial de análise de políticas públicas (HAM e HILL, 1993) e, particularmente, na abordagem

4 Tal como sugerido por Abrucio (2005), na gestão de políticas públicas a cooperação intergovernamental se faz necessária por várias razões, entre elas: aperfeiçoar o uso de recursos no caso de problemas de ação coletiva que atinjam mais de uma unidade federativa (como, por exemplo, as doenças transmissíveis por vetores e outros agravos cuja determinação e/ou controle envolvam mais de um município ou estado); auxiliar os governos com piores condições para exercerem suas responsabilidades evitando o "jogo de empurra" entre os entes; combater comportamentos predatórios e integrar o conjunto de políticas compartilhadas entre os governos; distribuir informações sobre administrações e experiências bem-sucedidas, incentivando o associativismo intergovernamental. 
do institucionalismo histórico (THELEN e STEINMO, 1992; HALL e TAYLOR, 2003; PIERSON, 2004), tendo como pressuposto a influência das instituições nas estratégias e preferências dos atores, nos rumos, trajetórias e conteúdo das políticas. A importância dos arranjos federativos e das relações intergovernamentais instituídas no Brasil para análise da política de saúde é um argumento-chave que permeia a discussão deste capítulo. Utilizaram-se como fontes principais de pesquisa a produção bibliográfica bem como resultados de investigações recentes sobre os temas em questão, que envolveram a participação de pesquisadores da Nacional de Saúde Pública Sergio Arouca da Fiocruz (Ensp-Fiocruz) ${ }^{5}$.

Três momentos foram considerados para desenvolvimento desse trabalho. Inicialmente, realiza-se um diagnóstico dos condicionantes político-institucionais que permeiam as relações intergovernamentais na política de saúde. Discorre-se sobre as características do pacto federativo consolidado no pós-88 (aspectos do sistema político, da Administração Pública e do federalismo fiscal) e suas implicações para a atuação do Estado na saúde. É feito, ainda, um balanço das políticas de descentralização e regionalização no SUS com ênfase nas mudanças e desafios associados ao Pacto pela Saúde, no período de 2006 a 2010.

Em seguida, aprofunda-se a análise da política de saúde segundo três mecanismos de coordenação federativa recorrentes na literatura sobre o tema: (1) a divisão de responsabilidades e funções gestoras entre as autoridades governamentais no contexto do marco regulatório do SUS; (2) as entidades representativas, as instâncias e os instrumentos de pactuação federativa no SUS (negociação, decisões compartilhadas e formalização de compromissos entre os gestores); (3) o sistema de partilha de recursos financeiros na saúde.

Por fim, à luz do diagnóstico anterior, são apresentadas algumas diretrizes para o desenvolvimento da coordenação federativa do sistema de saúde nos próximos vinte anos, e sugeridos alguns desdobramentos futuros para concretização destas propostas.

5 Entre elas, destacam-se os projetos de acompanhamento da condução nacional da política de saúde durante o governo Lula (financiamento CNPq e PAPES-Fiocruz), em andamento a partir de 2008; e a pesquisa sobre os condicionantes da regionalização em saúde nos estados no contexto do Pacto pela Saúde, intitulada "Avaliação Nacional das Comissões Intergestores Bipartites (CIB): as CIB e os modelos de indução da regionalização no SUS”, realizada no período de 2007 a 2010. Este último trabalho caracterizou-se como um projeto interinstitucional envolvendo pesquisadores do Departamento de Medicina Preventiva da Faculdade de Medicina da Universidade de São Paulo, da Ensp-Fiocruz e do Instituto de Saúde Coletiva da Universidade Federal de Mato Grosso, tendo sido financiado pela Secretaria Executiva do Ministério da Saúde, em parceria com a Organização Pan-americana de Saúde e a Fundação Faculdade de Medicina da Universidade de São Paulo. Os resultados desta pesquisa encontram-se disponíveis em http://bvsms.saude.gov.br/bvs/descentralizacao/cibs/index.php. Também foram consolidados em livro recém publicado citado amplamente neste capítulo: VIANA, A.L.A. e LIMA, L.D (Orgs). Regionalização e relações federativas na política de saúde do Brasil. Rio de Janeiro: Editora Contra-Capa, 2011. 


\section{2 | CONDICIONANTES INSTITUCIONAIS DA ORGANIZAÇÃO POLÍTICO- TERRITORIAL DO SUS}

\section{1 | Dilemas Relativos ao Pacto Federativo Brasileiro}

Estudos sugerem que os conflitos políticos relacionados à divisão do poder territorial no Brasil tiveram início no período colonial (CARVALHO, 1996) e que as origens do pacto federativo no país remontam ao Império, quando são explicitados os poderes administrativos às então dezesseis províncias existentes, bem como suas competências relativas à tributação, à força policial e à participação nos processos decisórios nacionais (DOLHNIKOFF, 2005). No entanto, a instauração formal do federalismo se dá com a promulgação da primeira Constituição Federal Republicana em 1891. A adoção dessa forma de organização do Estado esteve relacionada à idéia de permitir maior descentralização e autonomia, face ao descontentamento das elites regionais com a centralização monárquica, buscando "manter junto" um país com fortes tradições localistas e heterogeneidades (ALMEIDA, 2001) ${ }^{6}$.

Entretanto, somente esse aspecto é insuficiente para compreender a conformação da federação brasileira. Abrucio (2003) argumenta que o federalismo no Brasil também se diferencia pela ausência do republicanismo na base do sistema político, pois o fim da monarquia respondeu mais aos anseios por descentralização do poder do que pela democratização da política. Para esse autor, a instauração da República se subordina a um "certo ideal federativo" quando, ao invés de descentralizar redesenhando a forma de atuação da esfera nacional, enfraquecemo-la em prol da maior autonomia e riqueza proclamada por alguns estados (principalmente São Paulo e Minas Gerais) e do fortalecimento de oligarquias que dominavam a política local.

Isso permitiu a governo central, ainda que limitado, atender a interesses políticos e econômicos locorregionais, por meio da canalização de recursos para poucas unidades territoriais, onde foram mantidas escassas as relações entre os entes da federação, em detrimento de um projeto de construção estatal nacional e abrangente. Nosso federalismo, portanto, nasce de modo centrífugo e hierárquico, mas também assimétrico e oligárquico no plano subnacional (ABRUCIO, 2003), características estas que demarcam ainda hoje a federação brasileira.

Ao longo da história, observa-se a alternância entre períodos de centralização e descentralização, relacionados aos regimes autoritários e à vigência da ordem democrática, que alteraram as relações de poder entre a União, os estados

6 Stepan (1999) buscou confrontar duas lógicas distintas que atuam na origem das federações: o federalismo como um arranjo político onde se juntam unidades político territoriais com autoridade política previamente existente (come together); o federalismo como um arranjo que mantém juntas unidades territoriais que poderiam aspirar trajetórias independentes (hold together). 
e os governos locais. Em seu estudo já clássico sobre o tema, Abrucio (1998) destaca o longo período do "unionismo autoritário" no Brasil, que vigorou como forma de relação intergovernamental na ditadura militar ${ }^{8}$, seguido pela conformação, nos anos 1980, de um arranjo "estadualista", consolidado com as eleições diretas para os governos estaduais e a vitória da oposição em $1982^{9}$.

Alguns estudos tendem a enfatizar os aspectos negativos desse arranjo, que dificultam a formulação e implementação das políticas públicas frente à situação de ingovernabilidade gerada e ao movimento predatório dos estados (ABRUCIO e SAMUELS, 1997; ABRUCIO, 1998 e 2001). No entanto, esse diagnóstico não é consensual entre os cientistas políticos que se dedicam ao tema ${ }^{10}$.

Um olhar minucioso sobre os anos 1990 mostra que foi possível implementar um programa amplo de estabilização econômica, encaminhar importantes reformas constitucionais e estabelecer limitações fiscais aos entes subnacionais a despeito do recrudescimento do poder dos estados na década anterior. Alguns autores assinalam que a extensão dos recursos de poder da Presidência da República no Brasil, auferida pela soma de poderes acumulada por sua tecnoburocracia no período nacional-desenvolvimentista (KUGELMAS e SOLA, 1999), e a visão centralizadora que predomina em nossa cultura política (ALMEIDA, 2005) ajudam a compreender a importância da União frente aos demais entes governamentais.

Assim, se o curto período "estadualista" em nossa federação existiu durante a redemocratização, é possível afirmar que ele entrou em crise ainda na primeira metade da década seguinte em função de uma série de mudanças decorrentes da própria Constituição de 1988, das prioridades federais e das condições políticas e econômicas do período recente. Tais mudanças alteraram o funcionamento das instituições federativas brasileiras, nas dimensões política, fiscal e administrativa, com implicações para as relações intergovernamentais.

7 A periodização do federalismo no Brasil já foi objeto de diversos trabalhos, com objetivos e perspectivas de análise distintas. Entre outros, Abrucio (1998), Kugelmas e Sola (1999), Viana, Lima e Oliveira (2002).

8 Este modelo firma-se sobre três pilares: o financeiro, o administrativo e o político. A centralização de receitas pelo Executivo Federal, a uniformização administrativa nas três esferas de governo e o controle das eleições dos governadores asseguravam a predominância da União sobre os demais entes federados.

9 O modelo "estadualista", em que o Executivo Federal perdeu forças para o Congresso Nacional, e a União para os estados, surge pelo fortalecimento do poder dos governadores, assentado sobre: a coincidência temporal entre as crises do Estado desenvolvimentista e a do regime militar, aliado ao contínuo crescimento financeiro das unidades subnacionais; ao papel dos governadores na transição democrática; à importância das eleições estaduais no sistema político-eleitoral (tanto em relação à Presidência, como também às Assembléias Legislativas e às prefeituras municipais), e; à crise do presidencialismo brasileiro durante a década de 1980 e início dos anos 1990.

10 Almeida (2001), por exemplo, concorda com a tese de Abrucio de que os estados são atores políticos historicamente importantes, que exercem influência sobre suas bancadas no Congresso, sobre as eleições municipais e a conformação dos partidos, o que os torna, na metáfora utilizada por Abrucio, verdadeiros "barões da federação". No entanto, pondera a falta de evidências que sustentem a afirmação de que o acúmulo de poder dos governadores os tenha transformado necessariamente em "jogadores com poder de veto" durante o período democrático, dificultando a realização da agenda de reformas pelo Executivo Federal. 
Em primeiro lugar, destaca-se o fortalecimento dos municípios no sistema político nacional, que são transformados em entes federativos com o mesmo status jurídico-constitucional que os estados e a União, tendo suas competências e prerrogativas asseguradas por força da Lei Constitucional e do Poder Judiciário ${ }^{11}$. 0 Brasil, portanto, diferentemente das demais federações existentes no mundo, possui soberania partilhada por três esferas de governo, refletindo uma longa tradição do poder local no país ${ }^{12}$. $O$ reconhecimento dos municípios como entes federativos foi também acompanhado por um processo importante de ampliação e descentralização de encargos sociais e recursos fiscais ${ }^{13}$, e intensificação do processo de emancipação de novos municípios.

Sobre a criação de novos municípios, levantamentos efetuados indicam que no período entre 1980 e 2001 foram instalados 1.570 municípios no país (BREMAEKER, 2001)14. Segundo dados do último censo do IBGE (IBGE, 2010), existem no Brasil 5.565 municípios (incluindo Brasília), sendo que cerca de 70\% possuem até 20 mil habitantes (Tabela 1). A população, no entanto, devido ao intenso processo de urbanização das últimas décadas concentra-se, na sua maioria (54\%), nos municípios com mais de 100 mil habitantes destacando-se entre eles os metropolitanos.

11 A Constituição Federal de 1988, em seu Art. 18, define que "a organização político-administrativa no Brasil compreende a União, os Estados, o Distrito Federal e os Municípios, todos autônomos nos termos da Constituição" (BRASIL, 1988).

12 Souza (2005) enfatiza esse aspecto ao analisar a forma como o federalismo foi desenhado nas sete constituições que regeram as instituições brasileiras após a promulgação da República, acentuando o processo de descentralização administrativa e fiscal ocorrido para os municípios em períodos que precederam a Constituição de 1988. Além disso, o "movimento municipalista" no Brasil ganhou contornos mais nítidos a partir dos anos 1980. Desde esta época, é possível observar uma participação e atuação organizada dos municípios nos debates políticos que envolvem a reforma do setor saúde (GOULART, 1996).

13 Os municípios foram os principais beneficiados pela ampliação de tributos na Constituição de 1988 (RESENDE e AFONSO, 2001; REZENDE, 2003). Das receitas totais cedidas pelo governo federal, a maior parte vai para as jurisdições locais por meio do Fundo de Participação dos Municípios (FPM). No que se refere aos estados, Prado (2003) estima que cerca de 30\% de suas receitas arrecadas são transferidas aos municípios, incluindo 25\% do Imposto sobre Circulação de Mercadorias e Serviços (ICMS), 50\% do Imposto sobre Veículos Automotores (IPVA), e 25\% do Fundo de Compensação pela Exportação de Produtos Industrializados (IPI-Exportação) recebido da União.

14 Segundo Bremaeker (2001), 31,8\% deles entre os anos de 1980 e 1991, 30,8\% em 1993, 34,0\% em 1997 e 3,4\% em 2001. Entre os estados, aqueles que apresentaram maior número de novos municípios no período entre 1980 e 2001 foram: Rio Grande do Sul (16,9\% do conjunto brasileiro); Minas Gerais (8,3\%); Paraná e Piauí (6,9\% cada); Santa Catarina (6,1\%); Tocantins e Maranhão (5,5\% cada); Mato Grosso (5,4\%); Bahia (5,2\%); Goiás (4,8\%); São Paulo (4,7\%); e Pará e Paraíba (3,8\% cada). 
Tabela 01. Distribuição dos municípios e da população segundo classe de tamanho dos municípios - Brasil, 2010

\begin{tabular}{l|r|r|r|r|}
\hline \multirow{2}{*}{$\begin{array}{l}\text { Classes de tamanho } \\
\text { dos municípios }\end{array}$} & \multicolumn{2}{|c|}{ Municípios } & \multicolumn{2}{c}{ População } \\
\cline { 2 - 5 } & $\mathrm{n}$. & \multicolumn{1}{c|}{$\%$} & \multicolumn{1}{c|}{. } & \multicolumn{1}{c}{$\%$} \\
\hline Até 2 000 & 118 & 2,1 & 197.429 & 0,1 \\
\hline De 2 001 a 5 000 & 1.183 & 21,3 & 4.176 .916 & 2,2 \\
\hline De 5 001 a 10 000 & 1.212 & 21,8 & 8.541 .935 & 4,5 \\
\hline De 10 001 a 20 000 & 1.401 & 25,2 & 19.743 .967 & 10,4 \\
\hline De 20 001 a 50 000 & 1.043 & 18,7 & 31.344 .671 & 16,4 \\
\hline De 50 001 a 100 000 & 325 & 5,8 & 22.314 .204 & 11,7 \\
\hline De 100 001 a 500 000 & 245 & 4,4 & 48.565 .171 & 25,5 \\
\hline Mais de 500 000 & 38 & 0,7 & 55.871 .506 & 29,3 \\
\hline Total & 5.565 & 100,0 & 190.755 .799 & 100,0 \\
\hline
\end{tabular}

Fonte: IBGE, 2010.

O fenômeno de emancipação dos municípios não é novo e decorre tanto das regras de partilha do Fundo de Participação dos Municípios (FPM) ${ }^{15}$ como da regulamentação sobre a criação, incorporação, fusão e desmembramento de governos locais ${ }^{16}$.

A feição "municipalista" do texto constitucional fortalece na arena política os atores municipais e coloca novos desafios para os processos de condução de políticas públicas. Por um lado, abre possibilidades de transformação da relação Estado e sociedade e de maior experimentação em nível local. Por outro, sabe-se que a maioria dos municípios brasileiros (os de pequeno porte populacional) não tem arrecadação própria significativa e depende das transferências intergovernamentais de recursos, com limitada capacidade de aumentar seu grau de autonomia política e financeira a partir do processo de descentralização (PRADO et al., 2003; LIMA, 2007a). Os gastos per capita com a manutenção dos quadros legislativos nas pequenas localidades, por vezes, superam as despesas com as políticas sociais (GOMES e MACDOWELL, 1999) e muitos municípios têm dificuldades administrativas, de formação e fixação de quadros

15 O desdobramento de um município, ao ratear sua base populacional, coloca-o em uma faixa populacional que atribui a ele um coeficiente de rateio relativamente mais favorável à apropriação dos recursos do FPM. Pela quantidade de recursos que o fundo mobiliza do Imposto de Renda e do Imposto sobre Produtos Industrializados arrecadados pela União, Dain (1995) pondera a existência no país de um incentivo financeiro potente à multiplicação de pequenos municípios.

16 Inicialmente, a Constituição definia que a criação de municípios deveria obedecer à legislação estadual e referendo da população diretamente interessada mediante a realização de plebiscito. Após a promulgação da Emenda Constitucional n.15 de 13 de setembro de 2006, novos municípios só poderão ser permitidos após divulgação dos Estudos de Viabilidade Municipal, apresentados e publicados na forma da Lei. 
públicos qualificados, o que limita as condições para o exercício dos governos locais (SOUZA, 2002).

Ressalta-se que, com exceção da educação que possui um dispositivo de transferência compartilhada entre os governos (OLIVEIRA, 2003) ${ }^{17}$, as relações fiscais predominantes, gerais e setoriais, se dão entre a União e os municípios, sendo pouco intermediadas pelos estados. As transferências estaduais, efetuadas por meio do ICMS, são particularmente importantes para as cidades médias e grandes, áreas com enormes carências, e onde vive a maior parcela da população. Entretanto, enquanto os principais mecanismos de transferência tributária adotados pelo governo federal são de natureza redistributiva (o FPM e as transferências automáticas do SUS), preponderam nas transferências regulares dos governos estaduais a devolução tributária (90\% dos recursos totais transferidos). Isso acaba por restringir os instrumentos a cargo dos governos estaduais, que possibilitariam a compensação financeira e diminuição das desigualdades na capacidade de gasto dos municípios.

Cabe ainda salientar que o elevado número de municípios no Brasil favorece a "pulverização da representação política" (DAIN, 1995), tornando mais complexo o processo de formulação e implementação de políticas públicas. Além disso, tal como alertam Daniel e Somekh (2001), a idéia da descentralização como sinônimo de municipalização induz a um pensamento autárquico, que pressupõe que os governos locais possam equacionar sozinhos suas próprias dificuldades. Essa visão equivocada estimula mais a disputa do que a conformação de estratégias e instrumentos de parceria entre os governos (PESTANA e MENDES, 2004). Para o SUS, onde a cooperação é condição fundamental para otimização de serviços, a competição desmedida entre os governos locais acaba comprometendo a própria configuração do sistema no território.

Um segundo aspecto importante a ser considerado diz respeito às condições de financiamento das políticas sociais no pós-1988. A análise da década de 1990 demonstra que a descentralização tributária era incoerente, sobretudo, com o modelo de atuação do Estado na economia e na proteção social desenhado após a inflexão conservadora nos anos seguintes à Constituição (LIMA, 2009). A descentralização associada à ampliação dos encargos sociais colidiu diretamente com os objetivos de liberalização econômica e retração do Estado, pois os investimentos e o aumento dos gastos públicos necessários à universalização da cobertura de serviços essenciais como os da saúde e educação eram incompatíveis com o equilíbrio fiscal ${ }^{18}$.

17 O Fundo de Manutenção e Desenvolvimento da Educação Básica e de Valorização dos Profissionais da Educação (FUNDEB)

18 Varsano (1996) indica que os estados e municípios, ainda que favorecidos pelo aumento de receita tributária, continuaram com dificuldades financeiras diante de suas dívidas passadas e aumento de suas despesas correntes. Entre 1988 e 1990, verifica-se que os governos estaduais aumentaram cerca de 2\% do PIB de sua receita disponível, despendendo cerca de $74 \%$ desse ganho com pagamento de pessoal. Nos municípios, 30\% da receita adicional foram gastos com aumentos de salários. As principais fontes de despesa foram justamente as áreas de saúde e educação, para quais as responsabilidades dessas instâncias ampliaram-se e onde ocorreram transferências importantes de equipamentos e serviços, além de grandes gastos com o funcionalismo público. 
Assim, foi necessário estabelecer formas para reapropriação de recursos e controle sobre os gastos para evitar uma ampliação ainda maior da transferência de recursos e das despesas públicas nos estados e municípios.

Lima (2007a) sistematiza os vários mecanismos utilizados pela União para recompor suas receitas tributárias e controlar o déficit fiscal decorrente dos aumentos das despesas nas esferas subnacionais de governo. Entre eles, destacam-se: a ampliação e contingenciamento das contribuições sociais que deveriam ser destinadas ao financiamento da Seguridade Social; o corte nos investimentos públicos federais; a implantação de condicionalidades para o repasse de recursos e renegociações da dívida pública com a União; as restrições legais sobre a gestão de recursos fiscais no nível subnacional.

Tais medidas incidiram nos orçamentos municipais e estaduais e no financiamento da saúde, frustrando expectativas de maiores benefícios associados à descentralização, mesmo após a vinculação de recursos estabelecida pela Emenda

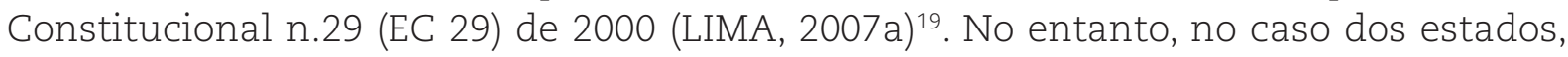
tiveram um impacto financeiro mais significativo, tendo em vista o alto grau de endividamento desses entes bem como às formas de renegociação do estoque de suas dívidas promovidas pelo governo federal (MORA, 1998; LOPREATO, 2000; MORA e VARSANO, 2001).

Durante os anos 1990, na esteira do abandono pelo governo federal das políticas de desenvolvimento regional, os estados passaram a utilizar seu poder de gestão sobre as alíquotas do ICMS como instrumento de política econômica, em prejuízo à arrecadação, com o objetivo de atrair novos investimentos e promover o desenvolvimento industrial, configurando o fenômeno de "guerra fiscal"20.

Prado e Cavalvanti (2000) indicam que a nova onda de investimentos privados nacionais e estrangeiros que se formou nesta época no Brasil impulsionou a disputa interestadual. Estados menos desenvolvidos, temendo perder investimentos

19 Um dos movimentos pela busca da estabilidade financeira da saúde no Brasil foi conduzido por parlamentares, buscando a vinculação de aportes para a saúde nos orçamentos das três esferas de governo. Após várias reformulações à proposta original, a EC 29 é aprovada em 13 de setembro de 2000 (BRASIL, 2000a), sete anos após seu primeiro envio ao Congresso. A EC 29 estabeleceu que a União deveria, em 2000, aplicar em ações e serviços públicos de saúde o montante de recursos empenhados pelo Ministério da Saúde em 1999, acrescido de pelo menos 5\%, ao passo que, no período de 2001 a 2004, deveria destinar à saúde o valor apurado no ano anterior, corrigido pela variação nominal do Produto Interno Bruto (PIB). Para os estados e municípios, os percentuais mínimos de vinculação são de, respectivamente, 12\% e 15\%, da receita de impostos diretamente arrecadados e das transferências tributárias constitucionais, deduzindo-se para o cálculo da base vinculável dos primeiros, as transferências obrigatórias para os municípios. Os dispositivos da EC 29 vigorariam até a publicação de uma Lei Complementar que até o momento não foi aprovada pelo Congresso Nacional.

20 O manejo das alíquotas do ICMS para atrair investimentos quando praticado sem a aprovação do conjunto dos estados é considerado ilegal no Brasil. No entanto, a falta de mecanismos regulatórios satisfatórios e a atuação do próprio Conselho Nacional de Política Fazendária (CONFAZ), composto pelos Secretários de Fazenda dos estados, acabaram acentuando sua ocorrência. 
em conseqüência das melhores condições dos principais centros industriais do país, passaram a oferecer maiores incentivos.

A partir de 2000, a Lei de Responsabilidade Fiscal (LRF) estabelece condições duras a serem observadas na gestão das contas públicas das diferentes esferas de governo e nos três Poderes para sustentar a disciplina fiscal (BRASIL, 2000b). A Lei enfatiza a transparência como condição para aumentar o controle dos contribuintes sobre as ações. Dentre os dispositivos de maior impacto para a gestão subnacional, destaca-se o limite de comprometimento da receita corrente líquida com o pagamento de pessoal, fixado em $60 \%$ para estados e municípios. O não cumprimento das obrigações leva a várias penalidades, inclusive incriminações pessoais.

Segundo Lopreato (2000), diante das limitações financeiras e das pressões para o ajuste fiscal, os estados "perdem capacidade de atuação".

A partir de 2004, os estados voltam a recuperar a sua capacidade de gasto devido ao crescimento econômico que se reflete nas receitas fiscais arrecadadas (principalmente o ICMS) e na geração de superávits. Entretanto, as restrições aqui destacadas não podem ser desconsideradas quando se analisa o desempenho dos estados em relação às suas despesas próprias com ações e serviços públicos de saúde e o descumprimento ainda freqüente em relação aos dispositivos da Emenda Constitucional 29 (MESQUITA, 2008).

Um terceiro elemento que tensiona as relações intergovernamentais, refere-se ao predomínio de competências comuns aos três entes no terreno das políticas sociais e do caráter concorrente da União e dos estados no que diz respeito à temática legislativa ${ }^{21}$, associado à insuficiência dos mecanismos de coordenação federativa existentes (BRASIL, 1988).

No Brasil, optou-se por uma modalidade de federalismo cooperativo, que introduz a possibilidade de execução conjunta e admite a participação de mais de uma esfera política nas tarefas governamentais (DALLARI, 1995). Segundo Almeida (2001), esse padrão é comum em diversas federações do mundo e permite maior flexibilidade na distribuição de responsabilidades em situações de expressivas desigualdades como é a brasileira. Simultaneamente, o constituinte remeteu à Lei Complementar a responsabilidade sobre a fixação de normas para a cooperação intergovernamental.

As políticas sociais, no âmbito de sua regulamentação específica, estabeleceram caminhos próprios para a repartição de competências e funções do Estado, e para a criação de arranjos e instrumentos de coordenação e cooperação

21 Segundo o Art. 24 da Constituição Federal, a União tem a competência de estabelecer normas gerais que podem ser complementadas por legislação estadual, desde que estas não sejam contrárias às regras mais amplas (BRASIL, 1988). Os estados podem exercer competência legislativa plena somente nos casos de ausência de legislação federal sobre as normas gerais. 
entre as instâncias de governo. A política de saúde, por exemplo, desenvolveu regras e instrumentos que possibilitaram sua adaptação em nível estadual, e impuseram ritmos e situações diferenciadas ao processo de descentralização do SUS, com flexibilidade para atender a situações de desigualdades das unidades subnacionais (ARRETCHE, 2000). Por outro lado, destaca-se a criação e o fortalecimento de instâncias de negociação e pactuação entre os gestores do SUS e o exercício da gestão compartilhada na saúde (MACHADO, LIMA e BAPTISTA, 2007).

Porém, ao mesmo tempo em que a questão da cooperação intergovernamental foi remetida para as políticas específicas, não foram revistos os espaços e mecanismos institucionais no âmbito mais geral da federação para gerar as condições políticas e econômicas necessárias à coordenação federativa.

Nesse sentido, chama atenção que a Lei Complementar para fixação das normas para cooperação não tenha entrado na agenda de discussões dos fóruns Legislativos, nem tenha sido objeto de votação do Senado, por excelência a câmara de representação dos estados e que deveria ter como foco as questões de interesse federativo. Mesmo no âmbito dos Executivos, há poucos espaços formais e não há tradição de debate e cultura de negociação política envolvendo os assuntos pertinentes à federação 22 . Vale ainda mencionar que, até 2005, não existia no Brasil uma legislação específica que apontasse as formas de consorciamento entre os entes da federação. Somente em abril de 2005 foi aprovada a Lei 11.107/2005, que dispõe sobre a contratação de consórcios públicos, regulamentada posteriormente através do Decreto 6.017/2007 (PEDREIRA, 2007) ${ }^{23}$.

Por último, cabe enfatizar a importante assimetria de poder entre esferas do mesmo nível de governo e a desigualdade entre elas. A desigualdade regional é uma marca da nossa federação desde seu nascedouro e até o hoje não foi suficientemente enfrentada pelos sucessivos governos, tendendo a aumentar frente ao processo atual de abertura da economia brasileira. Em que pesem as diferenças políticas e econômicas existentes, há uma tendência à adoção de regras uniformes para as esferas subnacionais, dificultando a adoção de políticas próximas a suas realidades e prioridades (SOUZA, 2005).

Noutro aspecto, o território, como elemento de síntese das desigualdades sócioeconômicas existentes, não se apresentou como objeto principal do planejamento nas diferentes áreas do governo durante toda a década de 1990, restringindo-se

22 Apenas em 2003, é criada uma estrutura no Executivo Federal — a Sub-Chefia de Assuntos Federativos — para auxiliar os governos, a Presidência e os Ministros de Estado, nos programas e projetos pertinentes à federação.

23 A ausência de Lei específica não inibiu a constituição de consórcios intermunicipais no Brasil. Segundo Pedreira (2007), no ano de 2005, somente na saúde, havia no país 1.907 municípios (34,3\% do total) participando de consórcios. A autora sugere que, tendo em vista a fragilidade do ordenamento legal, são os próprios entes federativos que começam a reivindicar um tratamento jurídico mais adequado ao tema. A legislação recente sobre os consórcios públicos vem a atender a estas demandas, mas sua aplicação parece bastante complexa e suscita questionamentos em relação ao papel dos estados no processo. 
às políticas de desenvolvimento macrorregional no plano nacional (GADELHA, MACHADO, LIMA e BAPTISTA, 2009). Segundo Brandão (2007), o período também se caracteriza pela defesa irrestrita das vicissitudes da escala local em detrimento da análise da natureza hierárquica da geração e apropriação da riqueza entre as múltiplas escalas intermediarias (e das mediações) que se impõem entre o local e o global. Tal postura embotou a capacidade política e técnica na construção de estratégias de desenvolvimento regional e, de certo modo, possibilitou a convergência de pensamento e a acomodação de interesses. Para a saúde, o avanço limitado da lógica territorial na condução da política e ênfase no "localismo" (ou da escala municipal) repercutiu diretamente no processo de descentralização e regionalização da saúde como será discutido a seguir.

O Quadro 1 sintetiza os principais dilemas associados ao pacto federativo brasileiro destacados nesta seção.

Quadro 01. Dilemas federativos que permeiam as relações intergovernamentais na saúde

\begin{tabular}{|c|c|}
\hline Dimensões & Dilemas federativos \\
\hline \multirow{7}{*}{ Política } & Predomínio de cultura política centralizadora \\
\hline & Fortalecimento dos municípios no sistema político \\
\hline & Pulverização e fragmentação de interesses no âmbito loco-regional \\
\hline & Oligarquização do poder local e regional \\
\hline & Governabilidade reduzida dos entes subnacionais \\
\hline & Limitações dos mecanismos de negociação intergovernamental \\
\hline & Insuficiência de mecanismos regulatórios entre os governos \\
\hline \multirow{5}{*}{ Fiscal } & Predomínio das relações fiscais entre a União e os municípios \\
\hline & Insuficiência dos mecanismos de equalização fiscal a cargo dos estados \\
\hline & Privilegiamento dos municípios na descentralização tributária \\
\hline & Endividamento e restrição da autonomia orçamentária dos entes subnacionais \\
\hline & Guerra fiscal entre os estados \\
\hline \multirow{5}{*}{ Administrativa } & Número elevado de municípios brasileiros com limitadas condições político-institucionais \\
\hline & Predomínio de competências comuns e concorrentes entre os governos \\
\hline & $\begin{array}{l}\text { Insuficiência dos espaços e mecanismos de coordenação e cooperação } \\
\text { intergovernamental }\end{array}$ \\
\hline & Assimetria de poder e desigualdades entre os governos subnacionais \\
\hline & $\begin{array}{l}\text { Uniformidade das regras nacionais e pouco enfrentamento das desigualdades territoriais } \\
\text { com estratégias regionais }\end{array}$ \\
\hline
\end{tabular}

Fonte: Adaptado de Lima, Machado, Baptista e Pereira, 2010. 


\section{2 | Balanço dos Processos de Descentralização e Regionalização da Política de Saúde no Período de 1990 a 2010}

A política de saúde desenvolveu mecanismos próprios de indução e coordenação, permitindo a acomodação das tensões federativas nos processos de descentralização e regionalização do SUS (ARRETCHE, 2002; VIANA e MACHADO, 2009). A regulação desses processos foi realizada pelo Ministério da Saúde por meio da normatização, consubstanciada pela edição anual de dezenas de portarias, em geral, associadas a mecanismos financeiros, que favoreceram a adesão e implementação das políticas pelos gestores locais e estaduais (MACHADO, 2007) e o aprendizado institucional das secretarias de saúde (VIANA et al., 2002).

De caráter transitório, as normas federais foram sendo complementadas e sucessivamente substituídas, sendo marcadas por debate cada vez mais intenso envolvendo as três esferas de governo e o Conselho Nacional de Saúde (LEVCOVITZ, LIMA e MACHADO, 2001). Nos anos 1990, foram publicadas quatro Normas Operacionais Básicas (NOB) e, em 2001, a Norma Operacional da Assistência à Saúde (NOAS, reformulada em 2002). A partir de 2006, foi instituído o Pacto pela Saúde, composto pelo Pacto de Gestão, Pacto pela Vida e Pacto em Defesa do SUS (BRASIL, 2006a e 2006b).

No plano nacional, os contextos históricos e político-institucionais relacionados à formulação e implementação dessas políticas propiciaram a revisão e atualização de procedimentos em vigor, sendo possível a identificação de elementos de continuidade e mudanças no marco regulatório do SUS (VIANA, LIMA e OLIVEIRA, 2002). Os elementos constitutivos da regulação encontram-se sistematizados no Quadro 1, considerando quatro aspectos-chave para os processos de descentralização e regionalização na saúde: (1) os mecanismos utilizados para a transferência de recursos federais (mecanismos de financiamento federal); (2) as formas de organização e prestação da atenção à saúde (modelos de atenção à saúde); (3) a integração das ações e serviços no território (racionalidade sistêmica); e, (4) as formas de relacionamento e divisão de funções e responsabilidades entre os governos (relações e acordos federativos). 


\begin{tabular}{|c|c|c|c|}
\hline 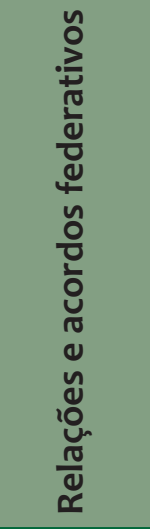 & 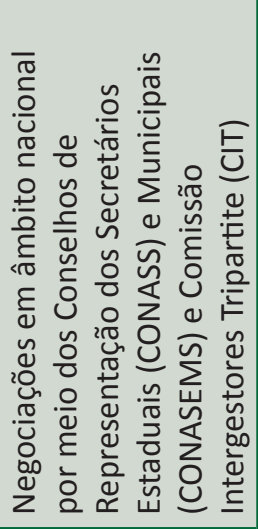 & 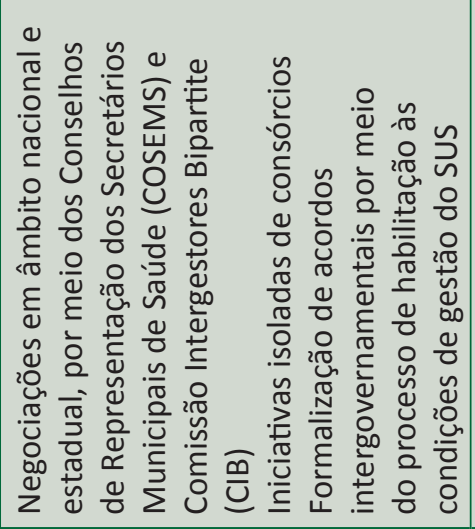 & 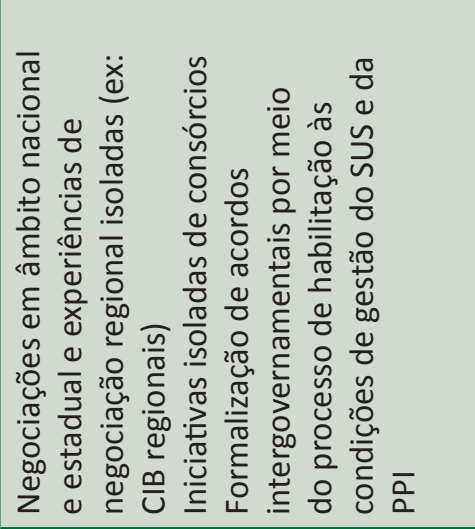 \\
\hline 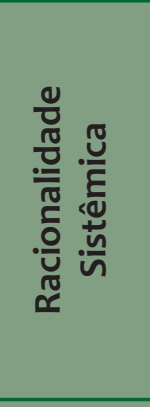 & 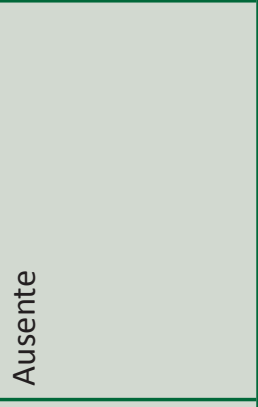 & 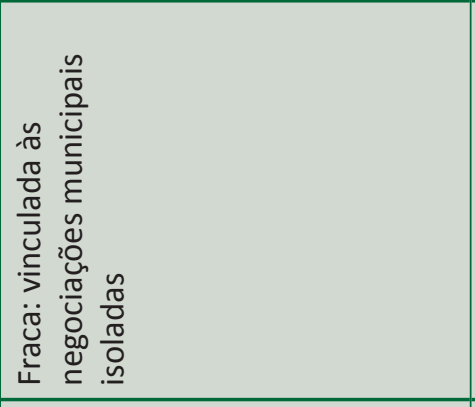 & 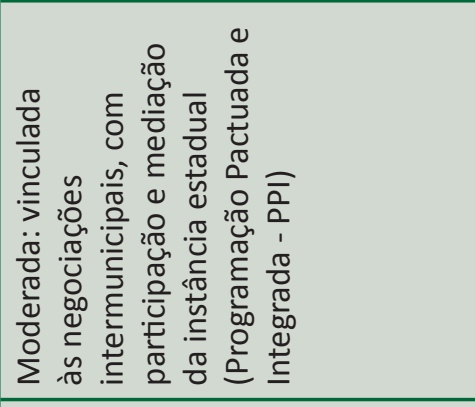 \\
\hline 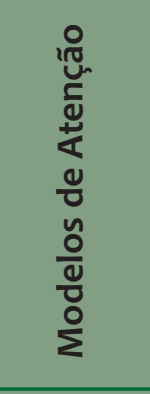 & 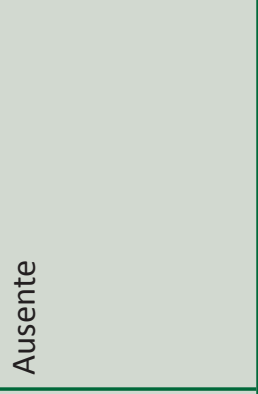 & 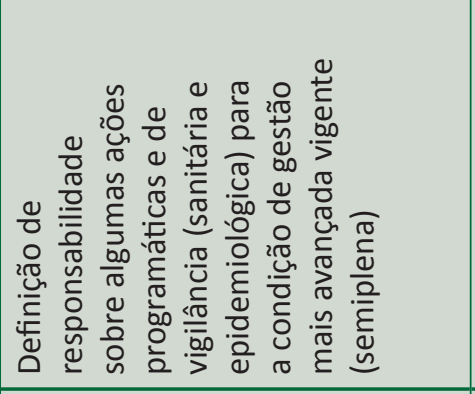 & 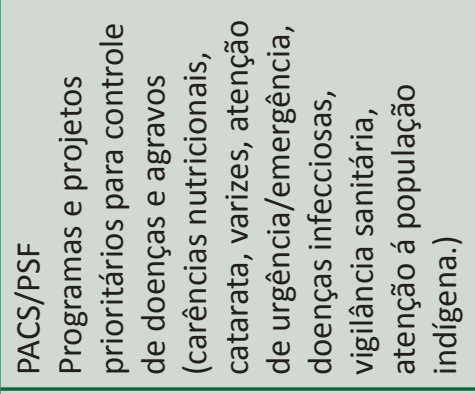 \\
\hline 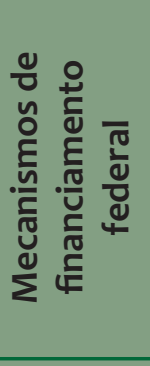 & 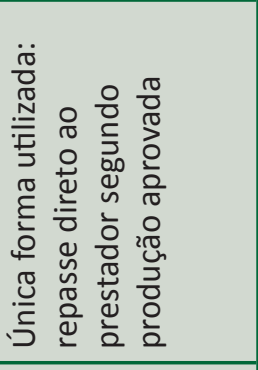 & 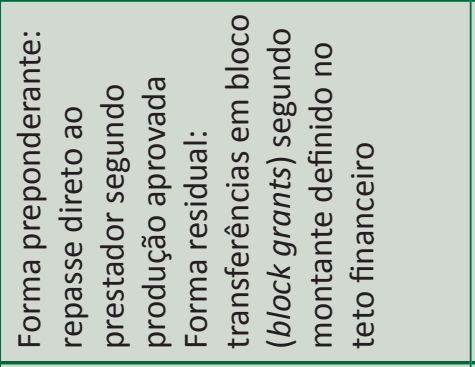 & 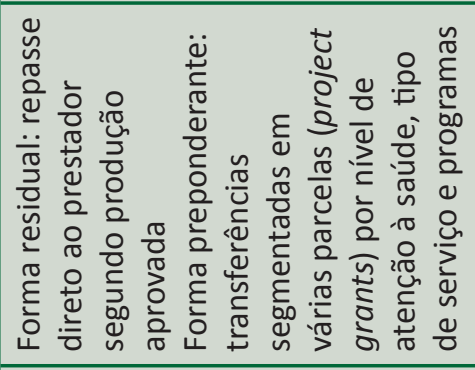 \\
\hline 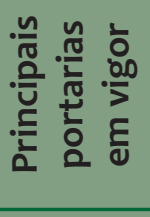 & $\begin{array}{l}\text { N } \\
\text { ने } \\
\text { कै } \\
\text { مू }\end{array}$ & $\begin{array}{l}n \\
0 \\
\infty \\
0 \\
2\end{array}$ & $\begin{array}{l}\text { o } \\
\text { ô } \\
\text { 2 }\end{array}$ \\
\hline$\frac{0}{\frac{0}{0}}$ & ஓ్ & નુ & જ̆ \\
\hline
\end{tabular}




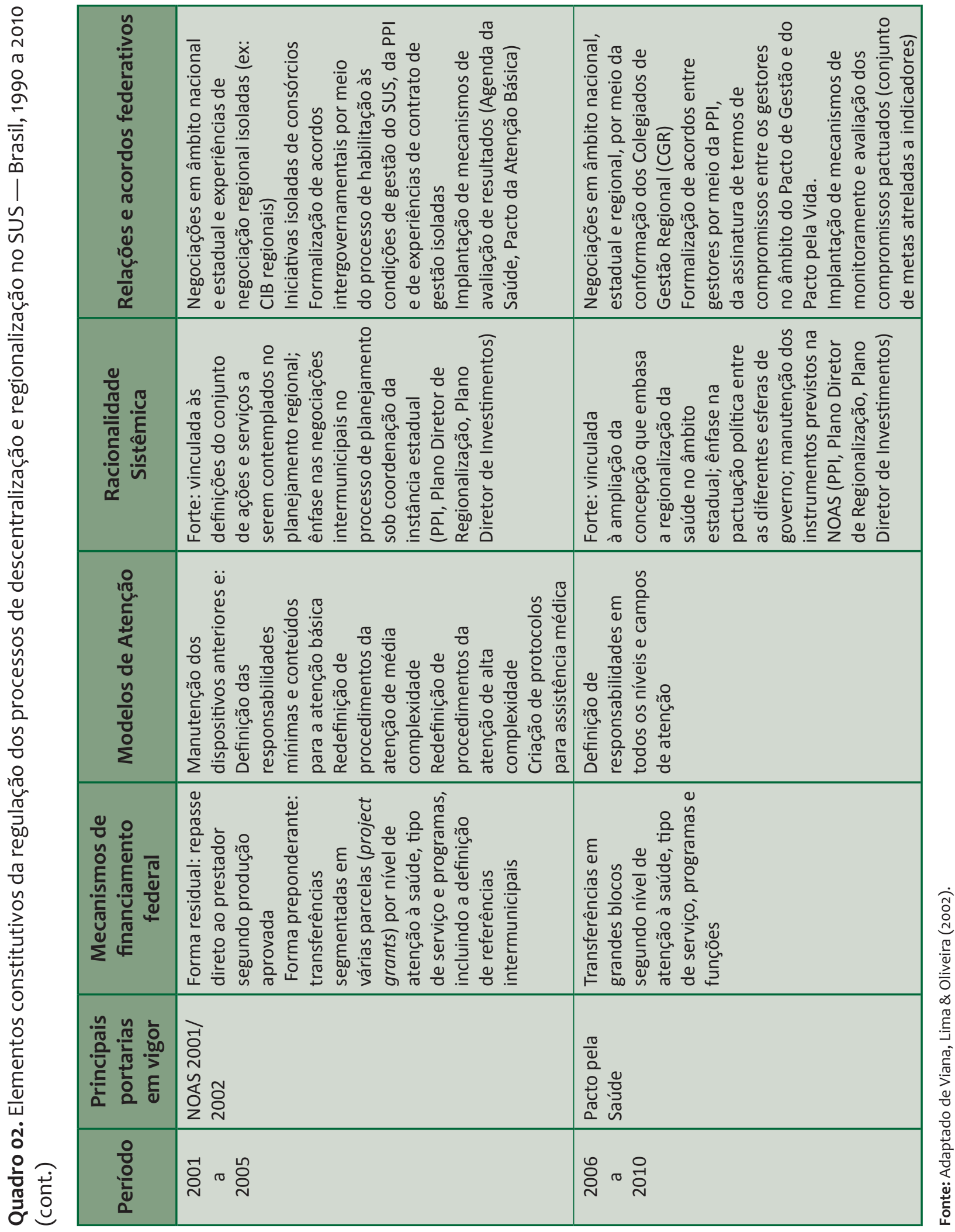


A análise das políticas federais desenhadas ao longo dos anos 1990 e 2000 permite aferir o descompasso entre os processos de descentralização e regionalização no SUS. Em que pesem os movimentos de centralização legislativa e financeira da função estatal destacados por alguns autores (ALMEIDA, 2007; ARRETCHE, 2009), a década de 1990 é testemunha da passagem de um sistema centralizado para um modelo em que milhares de governos municipais tiveram ganhos relativos de autonomia adquirindo uma atuação importante no campo da saúde ${ }^{24}$. Entretanto, a regionalização foi destacada de modo tardio na política nacional de saúde ${ }^{25}$.

As razões para o privilegiamento da estratégia de descentralização podem ser explicadas pelo próprio momento de constituição do SUS, quando a descentralização de recursos, competências e responsabilidades para as esferas subnacionais de governo foram identificadas no discurso contra o regime militar e o autoritarismo, com a ampliação da democracia e maior eficiência governamental26. Sem embargo, outros fatores devem ser considerados na explicação da experiência brasileira, caracterizada pela dissociação entre os processos de descentralização e regionalização.

A descentralização, reduzida em seu significado precípuo, não se configurou num projeto estratégico de intervenção econômica e social com vistas ao desenvolvimento (GADELHA et al, 2009). Pelo contrário, a agenda desenvolvimentista foi substituída pelo debate da redemocratização do Estado nos anos 1980 e pela busca de estabilização monetária nos anos 1990 (SALLUM JR., 2004), tendo sido possível adequar a descentralização aos projetos de enxugamento do Estado e de estabilização macroeconômica, num contexto de restrição fiscal e financeira ${ }^{27}$.

Neste contexto, as condições para um projeto de descentralização virtuoso, que atendesse às finalidades da política nacional de saúde - de garantia do acesso universal às ações e serviços de saúde e da atenção integral compatível com as necessidades e demandas diferenciadas da população — não foram asseguradas. Em conseqüência, os resultados da descentralização brasileira na saúde são contraditórios

24 Destaca-se que a descentralização na saúde envolve a transferência de poder decisório, da gestão de prestadores públicos e privados, da apropriação e execução de recursos financeiros, antes concentrados na esfera federal para estados e, principalmente, para os municípios.

25 Embora prevista como um princípio do SUS, a regionalização é reforçada somente a partir de 2000, quando da edição da Norma Operacional de Assistência à Saúde (NOAS) e, de forma mais incisiva, após a publicação do Pacto pela Saúde em 2006.

26 Matrizes ideológicas e experiências diversas informam o processo de descentralização da política de saúde durante as décadas de 1980 e 1990 (RIBEIRO, 2009). Na agenda reformista da saúde a descentralização esteve atrelada a valores mais abrangentes, sendo concebida como processo fundamental para a universalização, a integralidade e a construção do próprio sistema de saúde (VIANA, 1994)

27 O processo de descentralização da saúde não colidiu diretamente com as idéias liberais fortalecidas durante os anos 1990 (MELO, 1996; COSTA, 2002, NORONHA e SOARES, 2001). Os ideais de democratização e de redução do tamanho do Estado, fundados em bases político-ideológicas diferentes, geraram certo consenso acerca da necessidade de se descentralizar a saúde e favoreceram sua implementação no SUS (RIBEIRO, 2009), ainda que com contornos diferentes do projeto original da reforma sanitária. 
e altamente dependentes das condições prévias locais (VIANA, FAUSTO e LIMA, 2003). Observa-se que as características dos sistemas descentralizados de saúde são bastante heterogêneas no território nacional, refletindo as diferentes capacidades financeiras, administrativas e operacionais para a prestação da atenção à saúde e as distintas disposições políticas de governadores e prefeitos (SOUZA, 2002).

O território também não se apresentou como objeto principal de análise e planejamento para as diferentes áreas de governo ao longo desse período, embora, na saúde, iniciativas esporádicas tenham se dirigido para regiões mais carentes (VIANA et al., 2007) ${ }^{28}$. Há, portanto, uma fragilidade da lógica territorial na formulação de políticas públicas. A falta de um planejamento regional das estratégias de descentralização comprometeu sua adequação às múltiplas realidades brasileiras. Com isso, não houve uma diversificação de políticas e investimentos que melhor relacionasse as necessidades de saúde às dinâmicas territoriais visando à redução da iniquidade em diferentes planos.

Sem a face da regionalização, a descentralização acoplou-se ao desenho federativo consolidado pelas regras constitucionais brasileiras, desconsiderando o papel das esferas estaduais de governo e acentuando as atribuições dos municípios na provisão de serviços. Em que pesem os resultados positivos do processo de municipalização - entre outros, a ampliação do acesso à saúde, a incorporação de práticas inovadoras no campo da gestão e da assistência à saúde e a incorporação de novos atores que dão sustentabilidade política e financeira ao setor — permanecem problemas relativos à intensa fragmentação e à desorganização de serviços de saúde devido à existência de milhares de sistemas locais isolados.

Assim, o balanço que se faz do modelo de descentralização no SUS até o início dos anos 2000 é de que o mesmo foi importante para a expansão da cobertura de serviços e recursos públicos provenientes dos governos subnacionais. Porém, não foi capaz de resolver as imensas desigualdades regionais presentes no acesso, utilização e gasto público em saúde, além de não ter conduzido à integração de serviços, instituições e práticas no território e à formação de arranjos mais cooperativos na saúde.

O Pacto pela Saúde, publicado em 2006 e ainda em vigor, busca maior coerência e aproximação entre os conteúdos do território (a regionalização) e as diretrizes da política de saúde (entre elas, a descentralização), bem como fortalecer a negociação e a pactuação intergovernamental nos processos de organização políticoterritorial do SUS.

O Pacto propõe a redefinição das responsabilidades coletivas dos três entes gestores e a definição de prioridades, objetivos e metas a serem atingidos no âmbito setorial

28 Neste aspecto, cabe ressaltar os esforços de formulação da política de saúde para a Amazônia Legal, bem como alguns incentivos financeiros criados no âmbito da atenção básica visando a compensação das desigualdades regionais. 
(BRASIL, 2006a; BRASIL, 2006b). Durante os anos de 2006 a 2010, vários documentos são produzidos com o objetivo de detalhar algumas propostas e instrumentos operacionais do Pacto pela Saúde, bem como de fornecer orientações para negociação intergovernamental e implantação de estratégias e políticas em áreas específicas. As proposições do Ministério da Saúde assumem a feição de compromissos pactuados reunidos em quatorze cadernos da série Pactos pela Saúde publicados até dezembro de 2010.

O Pacto pela Vida corresponde à definição de prioridades, que se traduzem em objetivos e metas de melhoria das condições de saúde da população acordadas pelas três esferas de governo. Já o Pacto em Defesa do SUS, indica a necessidade de um movimento político mais amplo que aumente a base de apoio à política de saúde nos governos e na sociedade. Por sua vez, o Pacto de Gestão, estabelece diretrizes para o aprimoramento da gestão do SUS em oito aspectos: descentralização, regionalização, financiamento, planejamento, Programação Pactuada e Integrada (PPI), regulação, participação e controle social, gestão do trabalho e educação na saúde.

Diferenciando-se dos instrumentos anteriormente adotados no âmbito do SUS, a formalização dos acordos intergovernamentais inclui diversos âmbitos da gestão e atenção à saúde. A adesão ao Pacto é feita por meio do preenchimento e assinatura de Termos de Compromisso de Gestão (TCG) pelos gestores, que devem ser aprovados e homologados nas respectivas Comissões Intergestores em âmbito estadual e nacional, substituindo os antigos processos de habilitação às Normas Operacionais do SUS. As mudanças nos mecanismos de financiamento federal envolvem a unificação das centenas de repasses realizados anteriormente, por meio da criação de seis grandes blocos para transferência de recursos vinculados ao SUS.

No que concerne à regionalização, destaca-se o resgate de seu conteúdo político, ao admitir que a organização do sistema de saúde deva levar em conta a diversidade dos elementos que caracterizam e distinguem o território brasileiro, enfatizando a importância da condução e adaptação estadual e restringindo as determinações federais nesse processo (BRASIL, 2006c) ${ }^{29}$. O Pacto reatualiza os instrumentos de planejamento da NOAS e amplia a visão da regionalização para além da assistência à saúde. Propõe-se, ainda, a implantação de instâncias colegiadas de gestão permanente dos espaços regionais definidos nos Planos Diretores de Regionalização

29 Segundo o Pacto, as regiões de saúde são recortes territoriais inseridos em espaços geográficos contínuos. Identificá-los é responsabilidade dos gestores municipais e estaduais, tendo como base a existência de identidades culturais, econômicas e sociais, assim como de redes nas áreas de comunicação, infra-estrutura, transportes e saúde. Nessas regiões, as ações e serviços devem ser organizados com o objetivo de atender às demandas das populações dos municípios a elas vinculados, garantindo o acesso, a eqüidade e a integralidade do cuidado com a saúde local. Para tanto, deve estar garantido o desenvolvimento da atenção básica da assistência e parte da média complexidade, assim como as ações básicas de vigilância em saúde. As Regiões de Saúde podem assumir diferentes desenhos, desde que adequados às diversidades locais, mesmo que não acompanhando as divisões administrativas regionais já utilizadas por alguns estados na organização de seus trabalhos. A delimitação das Regiões de Saúde não pode ser vista, portanto, como um processo meramente administrativo. Para que seja eficaz e efetiva, deve levar em conta todos os fatores envolvidos, viabilizando dessa forma o desenvolvimento de uma 'regionalização viva'. (BRASIL, 2006c: p.23). 
visando de ampliar a governança regional do SUS: os Colegiados de Gestão Regional $\left(\right.$ CGR) ${ }^{30}$ (BRASIL, 2009a; BRASIL, 2010).

Destaca-se que, no contexto do Pacto, a regionalização se associa a uma perspectiva mais ampla e integrada de transformação socioeconômica e de redução das desigualdades regionais, sendo amparada pela expansão do investimento público federal e estadual ${ }^{31}$, ainda que os problemas do financiamento na saúde permaneçam.

Em síntese, o Pacto pela Saúde representa uma inflexão nas relações federativas por enfatizar a necessidade de articulação de ações e cooperação intergovernamental na política de saúde de forma ampla, com valorização das esferas estaduais e municipais e criação de novas instâncias regionais.

Como demonstram estudos recentes, diversos são os fatores e a natureza dos fenômenos que condicionam e particularizam as experiências estaduais, influenciando os ritmos e graus de adesão ao Pacto pela Saúde e a implantação dos Colegiados de Gestão Regional (LIMA et al, 2011) bem como os diferentes estágios da regionalização no SUS (ALBUQUERQUE, IOZZI e MELLO, 2011)32.

Entre os fatores de natureza histórico-estrutural, destacam-se aqueles ligados às dinâmicas socioeconômicas e às características dos sistemas de saúde no plano loco-regional (VIANA, LIMA e FERREIRA, 2010) ${ }^{33}$. Entre os aspectos de ordem político-institucional, o legado de implantação de políticas prévias de descentralização e regionalização, o aprendizado institucional acumulado pelas instâncias do SUS (particularmente, os Conselhos de Representação dos Municípios e as Comissões Intergestores Bipartites) e pelos governos estaduais e municipais, a existência de uma dada cultura de negociação intergovernamental, a qualificação técnico-política da burocracia, e os modos de operação e condução das políticas de saúde nos estados. No que tange aos fatores conjunturais, os relacionados à ação política, como o perfil e trajetória dos atores sociais, a dinâmica das relações intergovernamentais e a prioridade da regionalização na agenda governamental, repercutem no processo decisório e nas escolhas realizadas.

30 No âmbito do Decreto 7.508, de 28 de junho de 2011 (BRASIL, 2011), estes passam a ser denominados como Comissões Intergestores Regionais.

31 Estimativas feitas com base no Sistema de Informações de Orçamento Público em Saúde e no Relatório Resumido da Execução Orçamentária da União (LEVI e SCATENA, 2011), demonstram que, no período de 2002 a 2008, o volume de recursos destinados ao financiamento do SUS pela União, estados e municípios aumentou cerca de 58\% em termos reais, de 76 bilhões para 119 bilhões (valores correspondentes à dezembro de 2009), o que representa um crescimento anual médio próximo a $10 \%$.

32 Neste estudo, os estados foram classificados segundo diferentes estágios da regionalização na saúde. Para tanto, consideraram-se duas variáveis principais: a institucionalidade (incipiente, intermediária e avançada) e governança (coordenada-cooperativa, coordenada-conflitiva, cooperativa, conflitiva, indefinida) do processo de regionalização.

33 A partir da aplicação de técnicas estatísticas (modelo de análise fatorial e de agrupamentos) as autoras identificaram cinco grupos de regiões conformadas pelos Colegiados de Gestão Regional na saúde, que se diferenciam segundo condições socioeconômicas e complexidade do sistema de saúde. 
No entanto, sugere-se a permanência de alguns desafios, sendo as estratégias e instrumentos propostos no âmbito do Pacto insuficientes per se para prover os avanços necessários à condução da descentralização e regionalização da saúde nos estados brasileiros.

Em primeiro lugar, a regionalização prevista no Pacto pela Saúde apresenta inúmeros conflitos com a descentralização tal como esta se realizou no Brasil. Isso porque a primeira (a regionalização) tem natureza complementar e se forma a partir de elementos de diferenciação e diversidade territorial; a segunda (a descentralização) se constituiu de maneira finalística, não complementar, pela redistribuição de responsabilidades e recursos para unidades político-territoriais específicas. Por essas razões, a regionalização, ao evocar maior responsabilidade das instâncias estaduais e redefinir o papel dos municípios, pode gerar a necessidade de revisão de acordos desprovidos de racionalidade sistêmica estabelecidos durante a descentralização anterior, indo de encontro a interesses já acomodados durante esse processo.

Também não estão claras as relações entre os processos de regionalização e a assinatura dos Termos de Compromisso de Gestão, que formalizam os acordos intergovernamentais no Pacto. Segundo estes dispositivos, a adesão dos governos subnacionais ao Pacto pode ocorrer sem que a regionalização seja de fato fortalecida ${ }^{34}$ e sem que esta represente qualquer avanço para a descentralização do sistema em âmbito estadual ${ }^{35}$.

Em segundo lugar, permanece o risco de desarticulação entre os processos de planejamento e de pactuação intergovernamental em curso nos estados, devido a pouca valorização dos instrumentos e recursos relativos ao planejamento regional no bojo da proposta (MACHADO, BAPTISTA e LIMA, 2010) ${ }^{36}$.

Em terceiro lugar, cabe mencionar a fragilidade do modelo de intervenção federal embutido na proposta do Pacto. Percebe-se pouca valorização do planejamento nacional, que não se restringe à coordenação de um processo "de base local e ascendente", visto que existem atributos próprios do planejamento em cada escala territorial.

Por outro lado, problemas de ordem estrutural como as desigualdades territoriais dificilmente podem ser resolvidos somente pela ação articulada dos estados

34 Este pode ser inclusive um grande empecilho para a adesão dos gestores municipais aos Termos de Compromisso de Gestão. Sendo a oferta de serviços especializados e de alta complexidade no SUS concentrada em poucas cidades, a meta só é exeqüível no plano regional exigindo a articulação entre diferentes gestores.

35 Este é um dos aspectos valorizado no âmbito do Decreto n. 7.508, de 28 de junho de 2011 (BRASIL, 2011), pois a assinatura dos Contratos Organizativos de Ação Pública, que substituem os Termos de Compromisso de Gestão do Pacto, deve expressar os compromissos dos gestores em âmbito regional.

36 Tentativas de articulação entre as estratégias de pactuação intergovernamental e a elaboração dos instrumentos de planejamento setoriais (os Planos dae Saúde, a Programação Anual de Saúde e o Relatório Anual de Gestão) visam minorar este problema (BRASIL, 2009 b; BRASIL, 2011). 
e municípios sem uma efetiva atuação do governo federal. As políticas setoriais, particularmente a descentralização e a regionalização, só poderão ter viabilidade se inseridas em políticas nacionais e estaduais de desenvolvimento regional de médio e longo prazo.

\section{3 | MECANISMOS DE COORDENAÇÃO FEDERATIVA NA SAÚDE}

\subsection{Divisão de Competências e Responsabilidades Gestoras no Contexto do Marco Regulatório do SUS}

A Lei Orgânica da Saúde (BRASIL, 1990) estabelece como órgãos responsáveis pelo desenvolvimento das funções de competência do Poder Executivo na área de saúde o Ministério da Saúde no âmbito nacional, e as secretarias de saúde ou órgãos equivalentes nos âmbitos estadual e municipal. A partir dessa definição, o termo "gestor do SUS" passou a ser amplamente utilizado em referência ao ministro e aos secretários de saúde. Mais do que um administrador, o gestor do SUS é a "autoridade sanitária" em cada esfera de governo.

Como enfatizado anteriormente, a legislação do SUS e diversas normas e portarias complementares editadas a partir dos anos 1990 empreenderam esforços no sentido de definir e diferenciar o papel dos gestores da saúde nas três esferas. No entanto, esta não é uma tarefa simples para os legisladores e formuladores de políticas, pois, dada a concepção de saúde na Constituição e a abrangência do próprio SUS, as determinações relativas à atuação do Estado na saúde envolvem um escopo de ações e serviços também bastante amplos. Além da organização da rede de assistência à saúde, compete ao Estado a execução de ações de vigilância sanitária, epidemiológica, saúde do trabalhador; a ordenação de recursos humanos para a saúde; a fiscalização e produção de insumos para a saúde; e a participação em outras políticas relevantes, como a de saneamento básico, fiscalização de produtos e proteção ao meio ambiente. Ressalte-se que várias destas responsabilidades implicam em parceria com outros setores de governo, como o desenvolvimento científico e tecnológico, a formação de recursos humanos, a provisão e regulação de insumos para a saúde, a política industrial, de urbanização, saneamento e educação, entre outros.

Em geral, a análise das funções delineadas para a União, estados e municípios nas políticas de saúde evidenciam a ausência de padrões de autoridade e responsabilidade claramente delimitados em diversos campos da política. Há também excesso de detalhamento em algumas áreas (por exemplo, a assistência à saúde) e escassez em outras (tais como a de formação de recursos humanos para a saúde). Na 
maioria das vezes, observa-se uma mistura entre competências comuns e concorrentes, e competências específicas de cada esfera nos diversos campos de atuação do Estado na saúde ${ }^{37}$, que nem sempre se coadunam com a escala de influência da atuação de cada gestor (nacional, estadual, municipal e regional, esta última em seus múltiplos recortes) ou têm coerência com as diferentes lógicas de organização dos serviços de saúde no território ${ }^{38}$.

A descentralização e regionalização do SUS, particularmente no contexto do Pacto pela Saúde, também induziram à reconfiguração das funções dos gestores no sistema de saúde, que se expressam de forma diversificada nos estados, de acordo com a área envolvida, as distintas realidades locorregional e as negociações intergovernamentais subjacentes a estes processos. Por exemplo, nos campos das vigilâncias epidemiológica e sanitária, cujos processos de descentralização são mais recentes, observam-se esforços de divisão de atribuições entre estados e municípios baseados em uma lógica de repartição por complexidade. Na assistência à saúde, por sua vez, a divisão de responsabilidades sofreu a influência de outras variáveis tais como os tipos de serviços oferecidos (ambulatoriais, hospitalares e de apoio diagnóstico e terapêutico; natureza, complexidade e direcionalidade das ações envolvidas; modelos adotados na prestação do cuidado, entre outras) e sua abrangência/escala territorial.

De forma geral, sugerem-se as seguintes tendências consolidadas no âmbito da política de saúde:

- Formulação depolíticaseplanejamento.A funçãodeformulação de políticas e planejamento é uma atribuição comum das três esferas de governo, cada uma em sua esfera de atuação, sendo estratégica a ação dos governos federal e estaduais para a redução das desigualdades regionais e locais. De modo geral, a formulação de políticas tem sido compartilhada entre os gestores do SUS no âmbito das Comissões Intergestores e dos Colegiados de Gestão Regional e com outros atores sociais, por meio dos Conselhos de Saúde, embora isso não se dê de forma homogênea entre os diversos temas da política. Em que pesem os esforços das esferas estaduais e municipais para elaboração de seus planos de saúde e as iniciativas de regulamentação desse processo, o conteúdo dos planos e a abrangência das ações planejadas variam enormemente no território nacional.

37 Segundo Machado (2007), em que pesem dificuldades conceituais e operacionais subjacentes à sua delimitação, cinco campos principais podem ser identificados: (1) assistência à saúde (inclui a regulação da assistência suplementar), (2) vigilância epidemiológica e controle de doenças, (3) vigilância sanitária, (4) desenvolvimento, produção e regulação de insumos para a saúde, (5) formação e gestão de recursos humanos para a saúde.

38 Sobre esse aspecto, Gadelha, Machado, Lima e Baptista (2009) enfatizam que há especificidades nos distintos âmbitos de atuação do Estado que têm implicações para a questão territorial. A complexidade, variedade e particularidade de cada uma delas podem dificultar uma perspectiva territorial mais integradora. 
$\mathrm{Na}$ esfera federal, apenas recentemente se registram instrumentos de planejamento formais que envolvam uma explicitação clara de prioridades e estratégias (MACHADO, BAPTISTA e LIMA, 2010), como a Agenda Nacional de Prioridades (em 2001), o Plano Nacional de Saúde Plurianual (publicado em 2004) e o Mais Saúde (lançado ao final de 2007). Na esfera estadual, destaca-se o Plano Diretor de Regionalização (PDR), o Plano Diretor de Investimentos (PDI) e a Programação Pactuada e Integrada (PPI) como instrumentos de planejamento regional e programação das ações e serviços de saúde no território.

- Financiamento. A responsabilidade pelo financiamento da saúde, segundo a legislação, deve ser compartilhada pelas três esferas de governo. A definição legal de um orçamento da seguridade social, as características do sistema tributário e as desigualdades da federação brasileira destacam a importância do financiamento federal na saúde. De fato, o peso do governo federal no financiamento da saúde ainda é importante, embora a participação relativa da esfera federal no gasto público em saúde tenha diminuído gradativamente desde o início da década de 1990, ao mesmo tempo em que houve aumento relativo da participação dos municípios e dos estados. A Figura 1 apresenta a participação da União, estados e municípios no financiamento público da saúde no período recente.

Figura 01. Despesas da União, estados e municípios com recursos próprios em ações e serviços públicos de saúde (em R\$ bilhões de dezembro de 2009) — 2002/2008

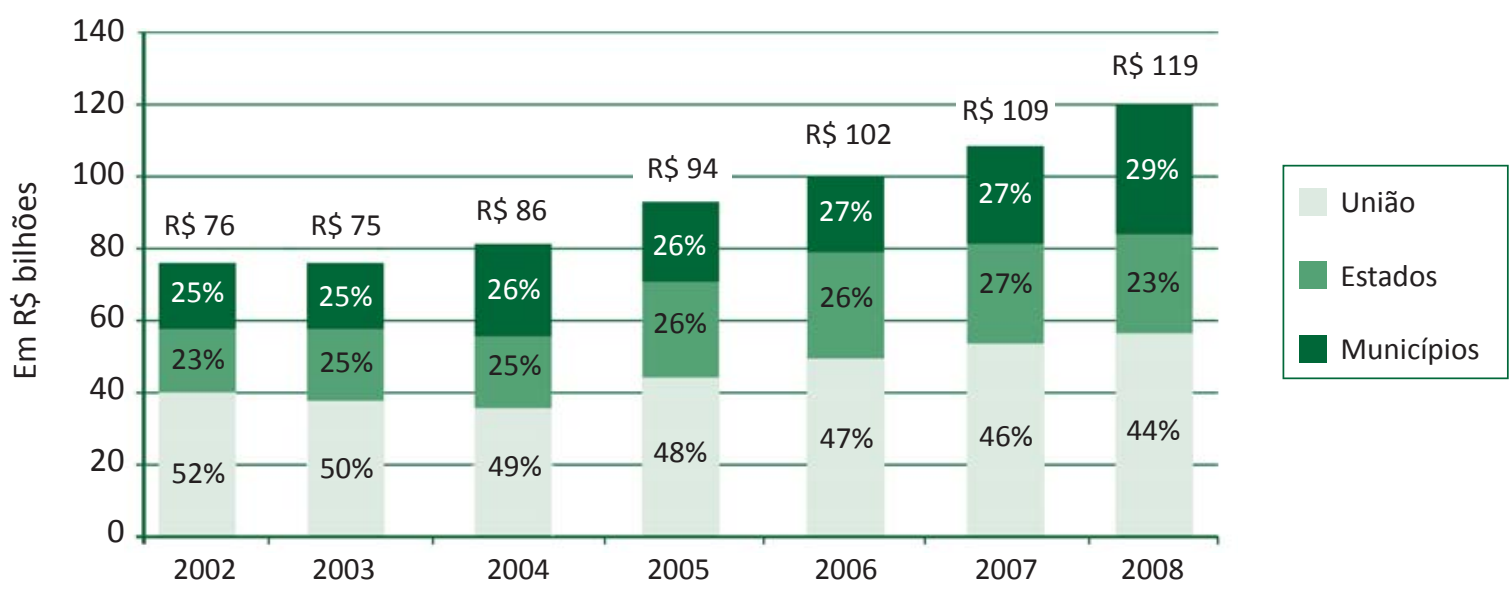

Fonte: SIOPS (estados e municípios) e Relatório Resumido da Execução Orçamentária da União. Extraído de Levi e Scatena, 2011. 
Sob a égide da Emenda Constitucional 29, o gráfico sugere que o crescimento do volume destinado ao SUS foi mais evidente nos estados (aumento de 92\% em termos reais) e municípios (80\%) na década de 2000, em contraste com o comportamento das despesas da União, as quais se elevaram em intensidade bem menor no período (aumento real de 31,2\%). Essa tendência de redução proporcional da participação da União no financiamento do sistema público de saúde já vinha se verificando anteriormente e indica a importância de se definir com maior clareza a parcela de recursos do orçamento federal a ser destinado à saúde em Lei Complementar (LEVI e SCATENA, 2011) $)^{39}$.

No que tange às relações intergovernamentais no financiamento da saúde, observa-se um aumento progressivo das transferências federais diretas para os gestores estaduais e municipais, tendo em vista o custeio das ações e serviços do SUS, que passam a exercer maiores responsabilidades sobre a execução dos recursos de origem federal. Estimativas feitas a partir do SIGA-Brasil indicam que as transferências federais representaram em 2009 cerca de 86,7\% da execução orçamentária do Ministério da Saúde com ações e serviços de saúde. Entretanto, grande parte dessas transferências é condicionada ou vinculada a programas específicos, o que restringe o poder de decisão dos demais gestores sobre os recursos transferidos e limita a capacidade da União em reduzir as desigualdades nas condições de financiamento em saúde dos estados e municípios ${ }^{40}$. Os gestores das três esferas de governo são responsáveis pela realização de investimentos que, em geral, não têm sido suficientes para a redução da iniquidade regional no SUS.

- Regulação. A responsabilidade de regulação sobre prestadores se desloca cada vez mais para os municípios, enquanto o Ministério da Saúde tem exercido seu poder regulatório principalmente sobre os sistemas estaduais e municipais, por meio de normas e portarias federais, atreladas a mecanismos financeiros. Aos estados, cabe a coordenação dos processos de regionalização, a regulação e articulação de sistemas municipais, o apoio à articulação intermunicipal, a

39 Entre os aspectos mais polêmicos dessa Lei em tramitação no Congresso Nacional destacam-se a alteração do critério de vinculação da União para, no mínimo, 10\% de suas despesas correntes brutas e a definição do conceito de despesas com ações e serviços públicos em saúde.

40 Os mecanismos de transferência federal serão aprofundados em item específico deste capítulo. 
coordenação da distribuição dos recursos financeiros federais nos municípios, a implantação de estratégias de regulação da atenção, a avaliação do desempenho dos sistemas municipais nos vários campos e o apoio ao fortalecimento institucional dos municípios. Aos municípios, atribuem-se as funções relativas à coordenação do sistema em seu âmbito, como a organização das portas de entrada do sistema, o estabelecimento de fluxos de referência, a integração da rede de serviços, a articulação com outros municípios para referências, a regulação e avaliação dos prestadores públicos e privados situados em seu território. A regulação sanitária continua sendo uma atribuição federal importante, comandada pela Agência Nacional de Vigilância Sanitária (Anvisa), com atribuições progressivamente assumidas por estados e municípios. A regulação de mercados em saúde representa uma área estratégica de atuação federal, tendo em vista os fortes interesses econômicos envolvidos no setor saúde.

- Prestação de serviços de saúde. Durante os anos 1990 ocorreu progressiva transferência de responsabilidades pela execução direta de ações e serviços para os estados e, principalmente, para os municípios, no âmbito da assistência à saúde, da vigilância epidemiológica e da vigilância sanitária. Grande parte dos municípios recebeu unidades de saúde de outras esferas, expandiu o quadro do funcionalismo e a rede de serviços próprios. No entanto, ainda se destaca a importância da prestação de serviços pelo gestor estadual nas regiões Norte e Nordeste do país. Atualmente, o gestor federal é executor direto de serviços em situações excepcionais (hospitais universitários e alguns hospitais federais localizados no município do Rio de Janeiro, Porto Alegre, Brasília e Belém).

Em síntese, o Ministério da Saúde continuou a ter uma função importante na condução da política nacional de saúde, por meio da indução e regulação de políticas, exercendo seu poder sobre outras esferas de governo, prestadores de serviços e alguns mercados em saúde. Os municípios ganharam imenso destaque na política de saúde pelo aumento de suas responsabilidades no planejamento, no financiamento, na regulação e na prestação de serviços de saúde no âmbito local. Aos estados, por sua vez, cabe o importante papel de conduzir e coordenar os processos de regionalização em saúde em parceria com os municípios, o que exige uma atuação direcionada dos governos estaduais para consolidação das redes regionalizadas de atenção à saúde e sua condução político-administrativa nas diferentes regiões do país (LIMA et al, 2010). 


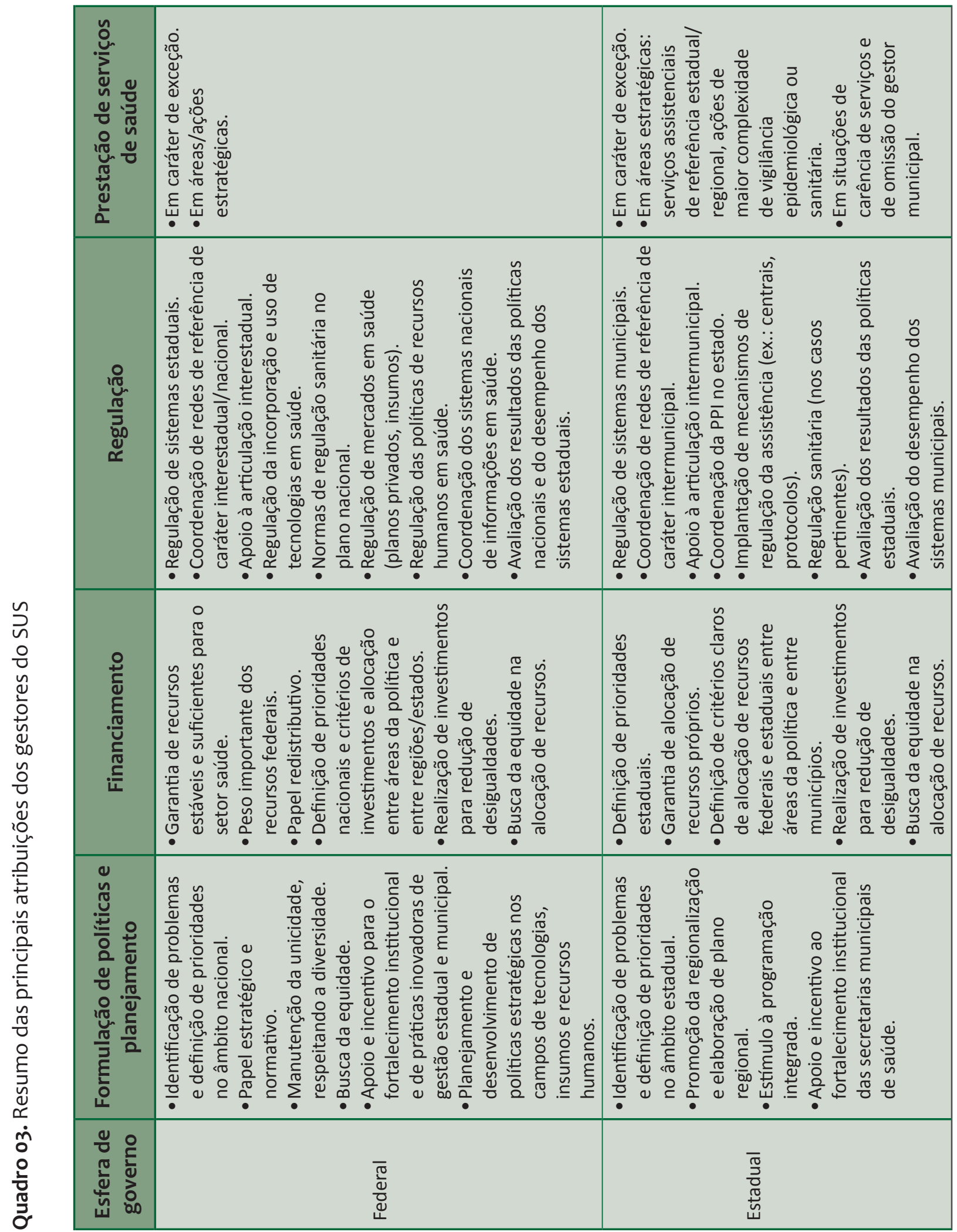




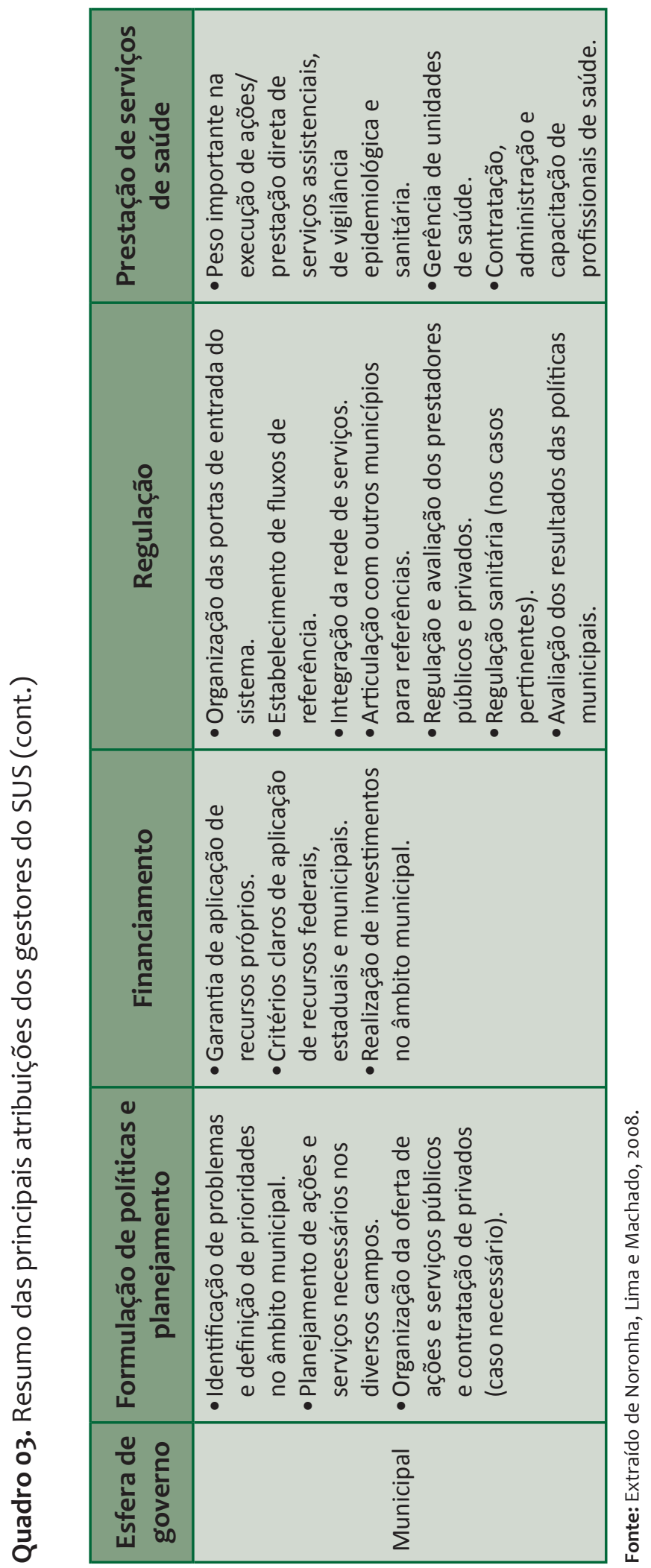




\subsection{Entidades Representativas, Instâncias e Instrumentos de Pactuação Federativa no SUS}

A atuação política do gestor do SUS envolve processos de negociação permanentes com outros representantes do poder público - incluindo os demais órgãos governamentais do Poder Executivo e de outros Poderes - em diversas escalas territoriais e esferas governamentais. O modelo institucional vigente na saúde também possui diversos agentes e órgãos governamentais, conselhos de representação e instâncias colegiadas, com o propósito de viabilizar a negociação e o acordo federativo e fortalecer e a participação social nas políticas de saúde (Figura 2).

Figura 02. Arcabouço institucional e decisório do SUS

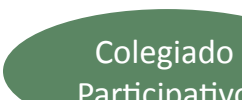

Participativo

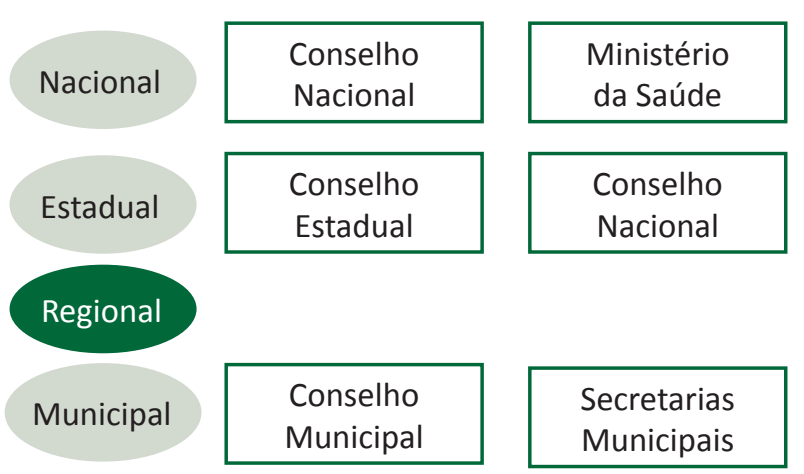

Fonte: Adaptado de Secretaria de Atenção à Saúde (Brasil, 2002).
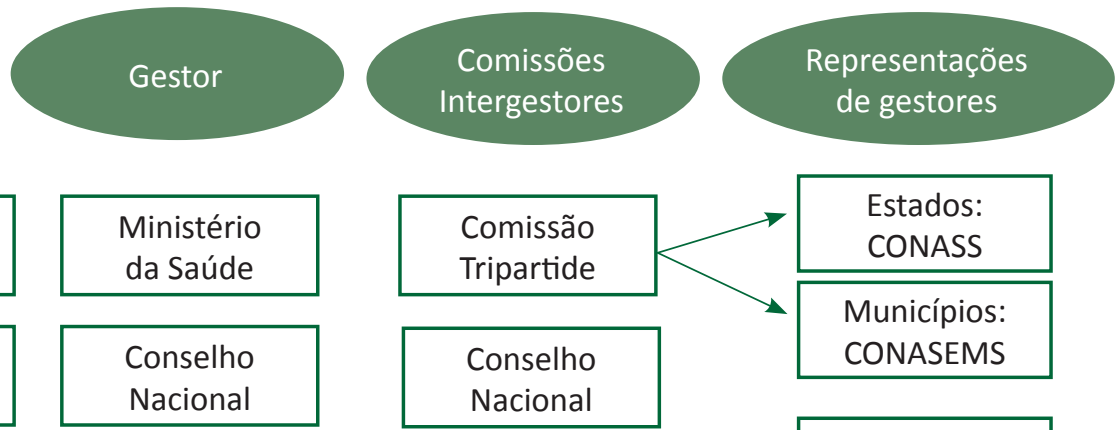

Colegiados de

Gestão Regional

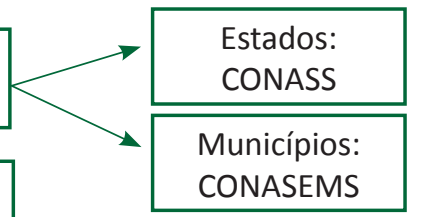

Municípios: COSEMS

Dessa forma, seja pelo processo inerente à tomada de decisão, seja pelo arcabouço institucional do SUS ou pelas atribuições associadas à atuação do Estado na saúde, os gestores do SUS não exercem suas funções de forma isolada. Isso implica que seus objetivos e planos de ação sejam negociados com diferentes atores governamentais e não governamentais, públicos e privados, e que os processos de formulação e implementação das políticas de saúde assumam cada vez mais uma feição compartilhada entre as instâncias de governo e os representantes da sociedade.

Com um enfoque mais restrito sobre o processo que envolve a tomada de decisão na saúde e todas as influências em jogo que permeiam a atuação dos gestores, serão destacadas aqui as formas de organização e funcionamento das instâncias de representação, negociação e pactuação federativa no SUS e o papel de alguns instrumentos utilizados na saúde para a consolidação de parcerias e formalização de acordos intergovernamentais. As instâncias incluem as arenas de gestão 
intergovernamental, em âmbito nacional, estadual e regional; e os instrumentos, os consórcios de saúde, os Termos de Compromisso de Gestão previstos no Pacto pela Saúde e os contratos estabelecidos entre entes governamentais. Serão enfatizados os avanços, limites e possibilidades deste modelo, tendo em vista os novos requisitos trazidos pela regionalização.

\subsection{1 | Os conselhos de representação dos secretários de saúde}

O Conselho Nacional de Secretários de Saúde (Conass), que é o conselho de representação nacional dos secretários estaduais de saúde, foi fundado em fevereiro de $1982^{41}$. O objetivo era tornar mais atuantes o conjunto das secretarias de saúde dos estados e do Distrito Federal no processo de reforma da saúde em uma conjuntura de abertura política e de redemocratização do país. Mas foi, ao longo da década de 1990, na luta por recursos estáveis para o sistema de saúde brasileiro e para ampliação do processo de descentralização da gestão do SUS, que o Conass progressivamente firmou-se como entidade representativa de gestores.

Entre os órgãos diretivos do Conass, destacam-se sua diretoria, formada por um presidente e cinco vice-presidentes regionais e assembleia geral. A assembleia geral é o órgão máximo da entidade, com poderes deliberativos e normativos da qual fazem parte todos os seus membros efetivos. As reuniões da assembleia geral são ordinárias ou extraordinárias, sendo realizadas no mínimo seis vezes ao ano. A assembleia geral tem competência para eleger os órgãos diretivos do Conass, para deliberar e normatizar sobre todos os assuntos de interesse do SUS e do conjunto das secretarias de saúde dos estados e do Distrito Federal.

A diretoria do Conass é assessorada tecnicamente por uma secretaria executiva desde novembro de 2002 (antiga secretaria técnica do Conass), formada por técnicos, geralmente egressos das secretarias de saúde dos estados e do Distrito Federal. Subordinada à secretaria executiva existem as câmaras técnicas, como as de Gestão e Financiamento do SUS, de Atenção à Saúde, de Assistência Farmacêutica, de Vigilância Sanitária, de Epidemiologia, de Recursos Humanos, de Informação e Informática.

Além das atividades de assessoria à diretoria, a secretaria executiva possui outras responsabilidades, tais como: representação e participação ativa nas negociações técnicas com os municípios e o Ministério da Saúde e outras instâncias decisórias do SUS; criação de instrumentos de difusão de informação entre as equipes das Secretarias de Estado de Saúde e outros profissionais de saúde; desenvolvimento

41 Posteriormente, a Lei Federal n. 8.142 de 1990 (BRASIL, 1990b), ao dispor sobre a participação da sociedade na gestão do SUS, define o Conass como representante dos estados no Conselho Nacional de Saúde. Já a NOB SUS 01/93 estabelece a participação do Conass na Comissão Intergestores Tripartite (CIT), legitimando seu papel na formulação e implementação da política nacional de saúde (BRASIL, 1993). 
de pesquisas e estudos de interesse comum dos gestores; apoio e assessoria direta a secretarias de estado de saúde, em temas específicos.

A formação do Conselho Nacional de Secretarias Municipais de Saúde (Conasems) é também anterior à legislação do SUS. Suas origens remontam a uma série de encontros entre secretários de saúde realizados desde o início da década de 1980, e se confundem com o movimento municipalista que se fortaleceu no contexto de democratização e desempenhou um papel importante na reforma sanitária brasileira. A primeira diretoria do Conasems foi empossada em $1988^{42}$ e, progressivamente, esta instância estabeleceu-se como um espaço legítimo e formal de participação dos secretários municipais na formulação e implementação da política nacional de saúde.

Entre os órgãos de direção do Conasems destacam-se sua diretoria, composta por um presidente e um vice-presidente e cinco vice-presidências regionais, além de várias secretarias extraordinárias formadas sobre temas específicos. Para melhorar a articulação entre os milhares de gestores municipais no país, o Conasems realiza encontros nacionais periódicos (no mínimo anuais) e conta com um conselho nacional de representantes estaduais (Conares) que reúne periodicamente os presidentes de todos os Conselhos de Secretarias Municipais de Saúde (Cosems) em âmbito estadual.

Portanto, em cada estado existem representações estaduais dos secretários municipais de saúde. A NOB SUS n. 01/93 estabelece que o órgão de representação dos secretários municipais de saúde no estado integre a Comissão Intergestores Bipartite (CIB), o que assegura a participação dos gestores municipais nas decisões sobre a política de saúde no âmbito estadual. Como será discutido a seguir, os critérios para seleção da representação dos secretários municipais na CIB diferem muito entre os estados.

O Conass, Conasems e os Cosems estaduais são espaços importantes para a articulação política e formação de pactos horizontais envolvendo os gestores da mesma esfera de governo. Destaca-se seu importante papel de apoio técnico, informação e aprendizado para as secretarias de saúde, especialmente aquelas com piores condições administrativas e as situadas em municípios de menor porte. São comuns a realização de assembleias gerais e/ou de encontros regionais, jornais periódicos, mala-direta, internet e endereço eletrônico como formas de organização, articulação entre os secretários e de divulgação de informações por esses conselhos.

Ressalta-se a pouca produção e investigação sobre o modo de funcionamento destas instâncias, particularmente, seu processo decisório interno,

42 De forma similar ao Conass, a Lei Federal n. 8.142 de 1990 estabelece que o Conasems tenha representação no Conselho Nacional de Saúde e a Norma Operacional Básica (NOB) n. 01/93 que esse conselho deva integrar a Comissão Intergestores Tripartite (BRASIL, 1990b; BRASIL, 1993). 
formas de representação e articulação dos interesses regionais e locais, poder de interferência sobre a política nacional e estadual de saúde e sobre as decisões tomadas nas instâncias decisórias do SUS, como as comissões intergestores. Entretanto, considerando que representam as secretarias de saúde nestas comissões, sua capacidade de organização e articulação de interesses repercute diretamente no modo de operação destas instâncias.

\subsection{2 | As comissões intergestores na saúde}

Na área da saúde, face à necessidade de conciliar as características do sistema federativo brasileiro e as diretrizes do SUS, foram criadas as Comissões Intergestores. O objetivo dessas instâncias é propiciar o debate e a negociação entre as três esferas de governo no processo de formulação e implementação da política de saúde, devendo submeter-se ao poder fiscalizador e deliberativo dos conselhos de saúde participativos.

A Comissão Intergestores Tripartite (CIT), em funcionamento desde 1991 no âmbito nacional, tem atualmente 18 membros, sendo formada paritariamente por representantes do Ministério da Saúde, representantes dos secretários estaduais de saúde indicados pelo Conass e representantes dos secretários municipais de saúde indicados pelo Conasems, segundo representação regional.

Ao longo da década de 1990, a CIT se consolidou como canal fundamental de debate sobre temas relevantes da política nacional de saúde, promovendo a participação de estados e municípios na formulação dessa política por meio dos seus conselhos de representação nacional e incentivando a interação permanente entre gestores do SUS das diversas esferas de governo e unidades da federação. A atuação da CIT se destaca particularmente nas negociações e decisões táticas relacionadas à implementação descentralizada de diretrizes nacionais do sistema e aos diversos mecanismos de distribuição de recursos financeiros federais do SUS.

A CIT foi de fundamental importância no processo de debate para a elaboração das normas operacionais que regulamentaram a descentralização no SUS, bem como do Pacto pela Saúde. Vale também assinalar que é comum a formação de grupos técnicos compostos por representantes das três esferas, que atuam como instâncias técnicas de negociação e de processamento de questões para discussão posterior na CIT. Sua dinâmica tem favorecido a explicitação e o reconhecimento de demandas, conflitos e problemas comuns às três esferas de governo na implementação das diretrizes nacionais, promovendo a formação de pactos intergovernamentais que propiciam o amadurecimento político dos gestores na gestão pública da saúde (LUCCHESE et al., 2003). No entanto, algumas pesquisas sugerem que diversas questões e decisões estratégicas para a política de saúde não passam pela CIT ou são 
ali abordadas de forma periférica e que as relações entre gestores nessa instância têm caráter assimétrico no que tange ao poder de direcionamento sobre a política (MIRANDA, 2003; MACHADO, 2007).

As Comissões Intergestores Bipartites (CIB) foram formalmente criadas pela Norma Operacional Básica de 1993. Esta norma estabelece a CIB como "instância privilegiada de negociação e decisão quanto aos aspectos operacionais do SUS" (BRASIL, 1993), ressaltando os aspectos relacionados ao processo de descentralização no âmbito estadual. Em cada estado há uma CIB formada paritariamente por representantes estaduais indicados pelo secretário de estado de saúde e representantes dos secretários municipais de saúde indicados pelo Cosems.

Os critérios para definição dos representantes dos municípios e do estado na CIB podem diferir bastante. Na maior parte das vezes, os representantes municipais são escolhidos em processos amplos de debate promovidos pelo Cosems, considerando critérios diversos, entre eles a distribuição regional dos municípios, o porte populacional e a liderança política dos gestores municipais. Ressalta-se que a adoção do critério regional para a definição desses representantes é frequente e tem se mostrado importante para a consideração da diversidade regional do sistema estadual de saúde. Além disso, em vários estados se procura promover uma alternância dos representantes municipais, mas, em geral, o secretário de saúde da capital tem assento na CIB. No que se refere aos representantes da secretaria estadual de saúde, estes, na sua maioria, possuem perfil técnico-político e respondem por áreas estratégicas para a definição e organização do sistema de saúde.

As CIB, cujas reuniões em geral apresentam periodicidade mensal, discutem tanto questões relacionadas aos desdobramentos de políticas nacionais nos sistemas estaduais e municipais de saúde (a questão da distribuição de recursos federais do SUS é um tema frequente) quanto referentes a agendas e políticas definidas no âmbito de cada estado. Em que pese a predominância dos temas relativos à organização da assistência à saúde, questões relativas às vigilâncias (principalmente epidemiológica), à educação em saúde, as políticas específicas e à gestão (financiamento, sistemas de informações, avaliação) são freqüentemente debatidas.

Assim como na CIT, o processo decisório nas CIB deve se dar por consenso, visto que é vedada a utilização do mecanismo do voto, visando estimular o debate e a negociação entre as partes. Segundo Miranda (2010), certa "racionalidade comunicativa" de interação nas CIB é predeterminada pela norma que atrela a decisão formal ao consenso. Entretanto, alguns constrangimentos podem ser observados nas negociações intergovernamentais devido aos prazos estipulados para os acordos e pelas próprias assimetrias de poder existentes entre as esferas de governo.

Outros autores indicam resultados positivos em relação aos processos decisórios instituídos nas CIB. Mesmo considerando o caráter especializado e restrito 
dessas instâncias, enfatiza-se a possibilidade da representação de diferentes grupos de interesse, a construção da parceria estado e municípios e da consolidação de uma prática de negociação entre os gestores mais equilibrada, democrática e participativa (RIBEIRO, 1997; LIMA, 1999; SILVA e LABRA, 2001).

A participação nas reuniões mensais geralmente é aberta a todos os secretários municipais e às equipes técnicas das secretarias, embora o poder de decisão se limite aos membros formais da comissão. Desta forma, muitas vezes as reuniões da CIB são momentos de intenso debate e interação entre as equipes municipais e destas com a estadual. Para os municípios, as CIB possibilitam a informação e atualização dos instrumentos técnico-operativos da política de saúde, a implementação dos avanços na descentralização do sistema de saúde, mas também a fiscalização das ações do estado na defesa de seus interesses, principalmente com relação à distribuição dos recursos transferidos pelo nível federal.

Na maioria dos estados, há câmaras técnicas bipartites que se reúnem mensalmente, antes da reunião da CIB, visando debater e processar as questões com vistas a facilitar a decisão dos representantes políticos na CIB. Em outros estados, essas câmaras não existem de forma permanente, mas é comum a formação de grupos técnicos (ou grupos de trabalho) para a discussão de temas específicos. A existência de estruturas para processamento técnico-político facilita a obtenção de consensos e a amenização de conflitos intergovernamentais.

As CIB permitem a adaptação das diretrizes nacionais do processo de descentralização em nível estadual, propiciando a formação de acordos e a redefinição de papéis entre as esferas subnacionais na gestão dos sistemas e serviços de saúde. Esses arranjos refletem não só a capacidade gestora, a qualificação gerencial das secretarias estaduais e municipais de saúde como também o grau de amadurecimento das discussões e as particularidades locais e regionais do relacionamento entre as diferentes instâncias de governo.

Em alguns estados existem CIB regionais, também de composição paritária, com o objetivo de permitir a discussão dos problemas de saúde e da organização da rede de serviços das diversas regiões do estado, bem como de propor soluções mais apropriadas às distintas realidades territoriais. As CIB regionais funcionam de forma bastante diversificada, mas, em geral, suas propostas ou decisões relevantes são referendadas pela CIB estadual.

Em recente pesquisa realizada sobre o tema (MACHADO et al, 2011), foi possível identificar o importante papel das CIB nesse processo. As CIB têm atuado na definição e pactuação de estratégias e instrumentos de regionalização (revisão dos Planos Diretores de Regionalização, Programação Pactuada e Integrada, debate sobre contratualização) e na implantação de estruturas de coordenação regional (os Colegiados de Gestão Regional). 
Por outro lado, a regionalização tem propiciado mudanças nas CIB, principalmente, nas suas formas de organização (alterações de regimentos e de suas estruturas regionais), representatividade (inclusão de critérios regionais de representação na CIB estadual e transformação de algumas CIB regionais em Colegiados de Gestão Regional) e operação (definição de fluxos de relacionamento com as estruturas regionais do estado e Cosems, com as CIB regionais e os Colegiados de Gestão Regional); nas relações intergovernamentais e nos conteúdos das negociações (ampliação de pautas regionais, sendo a regionalização um tema frequentemente debatido nas reuniões).

Entretanto, a dinâmica das CIB e sua importância na regionalização variam entre os estados, estando relacionadas à institucionalidade dessa comissão, bem como aos padrões de relacionamento e processos políticos estabelecidos para seu funcionamento como instância de negociação e pactuação do SUS. É possível afirmar que a ausência de canais permanentes de negociação entre estados e municípios (Câmaras Técnicas ou grupos de trabalho) desfavorece o estabelecimento de relações intergovernamentais cooperativas na CIB, comprometendo sua capacidade na definição da política. Por outro lado, o reconhecimento da relevância e legitimidade dessa comissão pelos altos dirigentes da secretaria de estado de saúde e a existência de um Cosems forte, política e tecnicamente, favorecem a coordenação intergovernamental da política de saúde por meio da CIB.

O mapa 1 apresenta a combinação das categorias institucionalidade e capacidade de atuação da CIB adotadas na pesquisa. A agregação destas duas categorias sugeriu uma relação entre ambas e permitiu agregar os estados em seis grupos, desigualmente distribuídos nas regiões do país. 
Mapa 01. Institucionalidade e capacidade de atuação da CIB-Brasil, 2007 a 2009

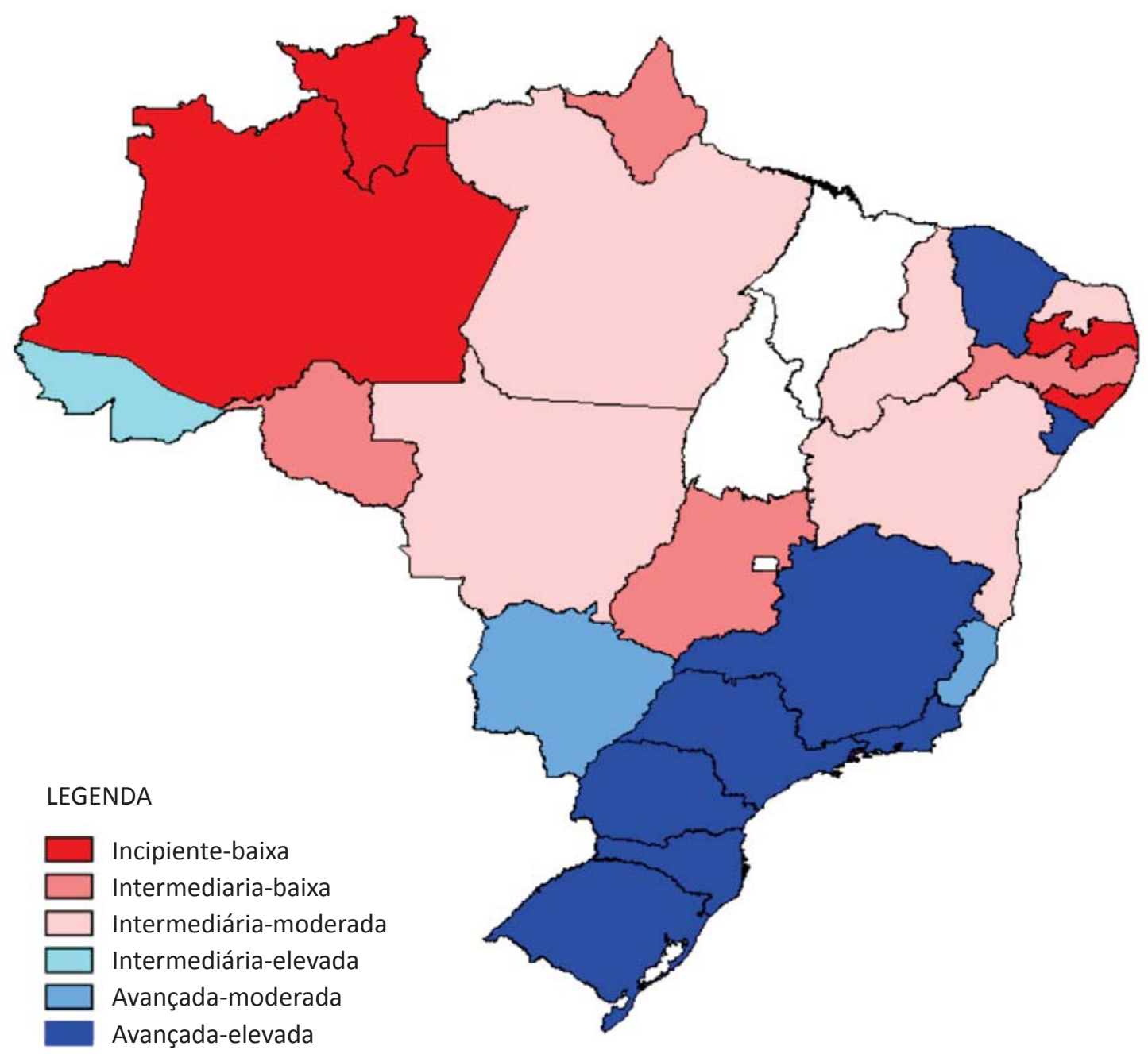

Fonte: Pesquisa "Avaliação nacional das Comissões Intergestores Bipartites (CIB): as CIB e os modelos de indução da regionalização no SUS" - Ensp/Fiocruz, FM/USP, ISC/UFMT. Extraído de Machado et al, 2011.

\subsubsection{Os colegiados de gestão regional (ou comissões intergestores regionais)}

Uma importante mudança trazida pelo Pacto pela Saúde diz respeito à implantação de instâncias colegiadas de gestão nos espaços regionais definidos nos Planos Diretores de Regionalização em cada estado: os Colegiados de Gestão Regional (CGR). Formados por representação do estado (do nível central ou das estruturas de representação regional das secretarias de estado de saúde) e do conjunto de municípios nas regiões (BRASIL, 2009a), os CGR permitem a criação de um canal permanente de negociação e decisão intergovernamental, com regras próprias e funcionamento estável. 
Tais Colegiados devem favorecer a identificação de problemas, a constituição de objetivos compartilhados, a definição de prioridades e propostas para organização e financiamento de uma rede regionalizada de atenção à saúde, estabelecendo uma lógica voltada para as necessidades regionais de saúde na provisão dos serviços (enfoque regional).

A exemplo do que se verifica em relação aos processos de adesão estadual e municipal ao Pacto, a implantação dos CGR teve seu inicio no ano de 2006 e tem obedecido a ritmos próprios em cada estado. Também são variadas as formas de organização e funcionamento dessas instâncias, sendo diferentes os modelos adotados para lidar com os contextos e lugares existentes.

Entre 2006 e setembro de 2010, foram implantados 417 CGR no país, que abrangem 5.332 municípios em 24 estados, dado que Roraima e Maranhão não instituíram Colegiados de Gestão Regional (Mapa 2).

Mapa 02. Ano de Implantação dos Colegiados de Gestão Regional nos estados. Brasil, 2006 a 2010

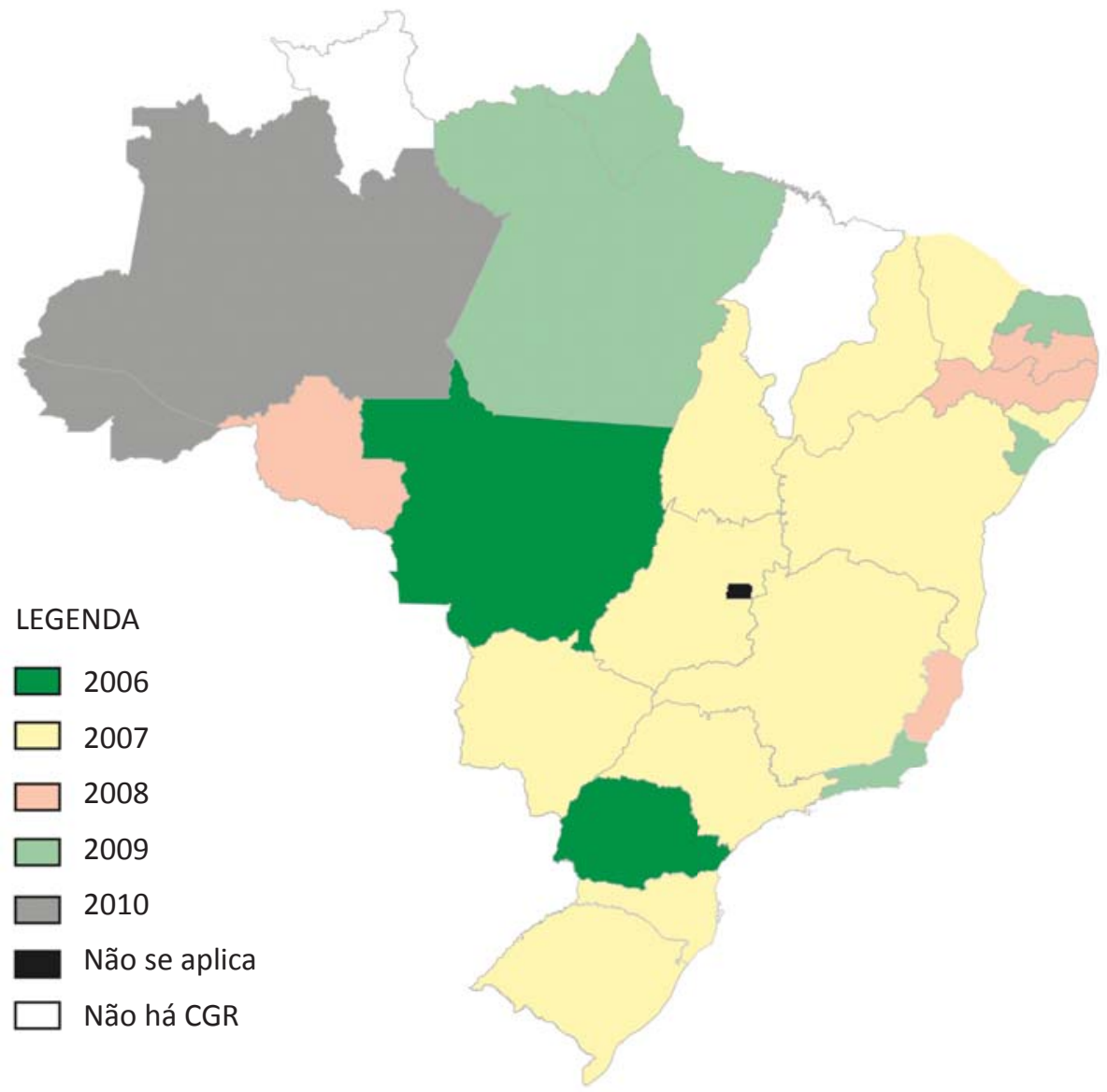

Fonte: Brasil. Ministério da Saúde, Departamento de Apoio à Gestão Descentralizada — DAGD/SE. 2010. Extraído de Lima et al, 2011. 
A implantação dos CGR tem sido influenciada pela prática de revisão e atualização do desenho regional adotado no âmbito estadual. Em alguns estados, essa atualização, ao ser realizada, considerou os conteúdos das propostas contempladas no Plano Estadual de Saúde, o que indica um esforço de alinhamento prévio entre instrumentos de planejamento que orientam as decisões gestoras no contexto do SUS.

Por outro lado, há situações nas quais os estados definiram seus Colegiados de Gestão Regional sem que tenha havido uma precedente revisão e atualização do Plano Diretor de Regionalização (PDR). Nestes casos, os CGR cumpriram os requisitos para sua formalização, mas apresentam dificuldades para se constituir como instâncias permanentes de negociação intergovernamental por não corresponderem aos arranjos regionais reconhecidos pelo conjunto de gestores do SUS na região. Tal situação dificulta a consolidação de uma cultura de debate e negociação pelo conjunto dos gestores e fragilizam a governança regional na saúde.

Também é preciso reconhecer que muitos CGR apresentam ainda funcionamento irregular e incipiente e, em geral, não possuem estrutura e recursos suficientes que permitam o desenvolvimento de parcerias e a resolução de conflitos federativos. Além disso, há necessidade de que os esforços setoriais busquem assegurar a implantação de fluxos e modalidades de relacionamento específico entre os CGR e outras estruturas regionais e colegiadas do SUS. Falta avançar na configuração de estratégias e instrumentos de planejamento, regulação e financiamento que possam apoiar a conformação de sistemas públicos de saúde nos espaços regionais definidos por essas instâncias.

\subsection{4 | Os consórcios de saúde}

Os consórcios de saúde representam parcerias estabelecidas entre entes de governo visando o alcance de interesses comuns, em geral com a finalidade de ampliar o acesso da população a determinados tipos de ações e serviços de saúde.

Apesar de existirem consórcios de saúde antes mesmo da Constituição Federal de 1988, os consórcios intermunicipais proliferaram de forma expressiva na segunda metade da década de 1990, particularmente entre os anos 1995 e 1996 (LIMA, 2000), de forma associada ao processo de descentralização. Os consórcios foram um mecanismo utilizado para suprir as necessidades de prestação de serviços especializados e de maior complexidade por um número expressivo de municípios com pequeno porte populacional ${ }^{43}$.

43 O primeiro consórcio intermunicipal de saúde surgiu na região de Penápolis, no estado de São Paulo, em 1987 (MONTEIRO, 1989). Inspirados por experiências prévias em outros setores (recuperação das várzeas, informática, alimentos e merenda escolar), esse consórcio foi fruto de uma junção de sete municípios que se associaram para tentar dar respostas a problemas comuns, bem como garantir o uso compartilhado de equipamentos de maior complexidade no sistema regional de saúde. 
A área da saúde é a que mais apresenta consórcios no país. Em 2005, segundo dados da IBGE, mais de 34\% dos municípios brasileiros participavam de consórcios de saúde (IBGE, 2007). Esta proporção aumenta no caso dos municípios com até 5 mil habitantes (43\%). Os estados que apresentavam maior número de municípios consorciados na área da saúde foram: Minas Gerais, Paraná, Santa Catarina, Rio Grande do Sul e São Paulo (PEDREIRA, 2007). No entanto, sabe-se que os propósitos e estruturas desses consórcios variam de modo significativo.

Os consórcios podem ser de diferentes tipos (comercial, empresarial ou administrativo), sendo que, na saúde, o mais comum é o administrativo. Nos consórcios administrativos os acordos consolidados são entre entidades da mesma espécie (o que os diferencia dos convênios), e têm por característica a inexistência de relações hierárquicas ou de subordinação, sendo que a inclusão ou exclusão dos membros pode ser realizada a qualquer momento (GUIMARÃES, 2001). Ademais, os compromissos de cooperação abarcam a realização de atividades temporárias ou permanentes, obras ou serviços de interesse público, podendo se voltar para a solução de problemas específicos (ex.: atenção à gestante e parturiente; saúde mental) ou para organizar um conjunto de serviços de atenção secundária e terciária na saúde. Os consórcios também podem ser unicêntricos, onde os membros canalizam esforços para a oferta de serviços em um município polo ou policêntricos onde repartem, por negociação, os diferentes serviços a serem prestados entre os municípios componentes do consórcio (MENDES, 2001).

Grosso modo, a maior parte dos consórcios de saúde conformados no Brasil surgiu das iniciativas próprias dos municípios, embora em alguns estados tenha ocorrido um processo de fomento ou apoio da secretaria estadual de saúde. Outra característica predominante nos consórcios existentes é a adoção de personalidades jurídica de direito privado (RIBEIRO e COSTA, 2000). Em algumas situações, tal movimento gerou certa confusão no âmbito da definição de papéis entre o estado e os consórcios. Além disso, assinalam-se as dificuldades na operacionalização do aporte de recursos públicos para o funcionamento de consórcios organizados nesses moldes.

Embora a Lei Orgânica da Saúde (BRASIL, 1990a) defina a possibilidade de consorciamento entre os municípios, no Brasil, até 2005, não existia uma legislação específica voltada para a conformação de consórcios públicos. Em função da grande quantidade de consórcios e da inexistência de regulamentação específica, a partir de 2003, há uma intensificação do debate entre o Executivo e o Legislativo culminando na aprovação da Lei 11.107 em abril de 2005 (BRASIL, 2005), que dispõe sobre a contratação de consórcios públicos. Essa lei foi regulamentada posteriormente através do Decreto 6.017 de 2007 (BRASIL, 2007).

De acordo com a lei, os Consórcios de Saúde devem seguir os princípios e diretrizes do SUS. Cabe destacar a complexidade do processo de conformação de 
consórcios pelas novas regras, que impõem uma série de passos e de negociações, incluindo a aprovação das propostas nas câmaras de vereadores de todos os municípios envolvidos (PEDREIRA, 2007). Além disso, pelo menos duas questões atuais se colocam para a readequação dos consórcios de saúde existentes: sua configuração em função dos recortes territoriais e objetivos expressos nos Planos Diretores de Regionalização; e, o estabelecimento de mecanismos formais de relacionamento com as instâncias de pactuação e gestão regional do SUS (Colegiados de Gestão Regional, CIB regionais, estruturas regionais das secretarias de estado de saúde).

\subsubsection{Termos de compromisso e contratos entre os entes federativos}

A expressão formal do processo de adesão estadual e municipal ao Pacto pela Saúde (formalização) ocorre mediante o preenchimento, a assinatura e a aprovação dos Termos de Compromisso de Gestão (TCG) nas respectivas CIB estaduais, seguidos por homologação na CIT. Há um modelo especifico de TCG para cada ente federativo - município, estado, Distrito Federal e União - justificado pelas diferentes responsabilidades previstas para cada um deles.

Os TCG compreendem atribuições e responsabilidades sanitárias, objetivos e metas de melhoria associados a um conjunto de indicadores, voltados para o monitoramento e avaliação do Pacto de Gestão e pela Vida, estando organizados em sete eixos prioritários: i) responsabilidades gerais de gestão do SUS; ii) responsabilidades sobre a regionalização; iii) responsabilidades sobre o planejamento e a programação; iv) responsabilidades da regulação, controle, avaliação e auditoria; v) responsabilidades sobre a participação e controle social; vi) responsabilidades sobre a gestão do trabalho; e, vii) responsabilidades na educação em saúde.

A adesão estadual ao pacto ocorreu de modo gradual no período compreendido entre 2006 e 2010, sendo que, atualmente, todos os estados do país estão com seus processos de adesão homologados na CIT e publicados em portaria ministerial.

A formalização dos TCG pelos municípios tem obedecido às dinâmicas locorregionais e ocorrido de modo mais ou menos articulado e complementar às adesões estaduais. No período compreendido entre 2006 e setembro de 2010, foram homologados na CIT 3.789 adesões ao Pacto, que representam cerca de 68\% do total de municípios existentes no país. O mapa 3 permite constatar que, nas regiões do centro-sul do país, este processo ocorreu de forma mais intensa, concentrando o maior numero de estados com percentual de adesão municipal superior a 70\%. 
Mapa 03. Proporção de adesões municipais ao Pacto pela Saúde nos estados — Brasil, 2010

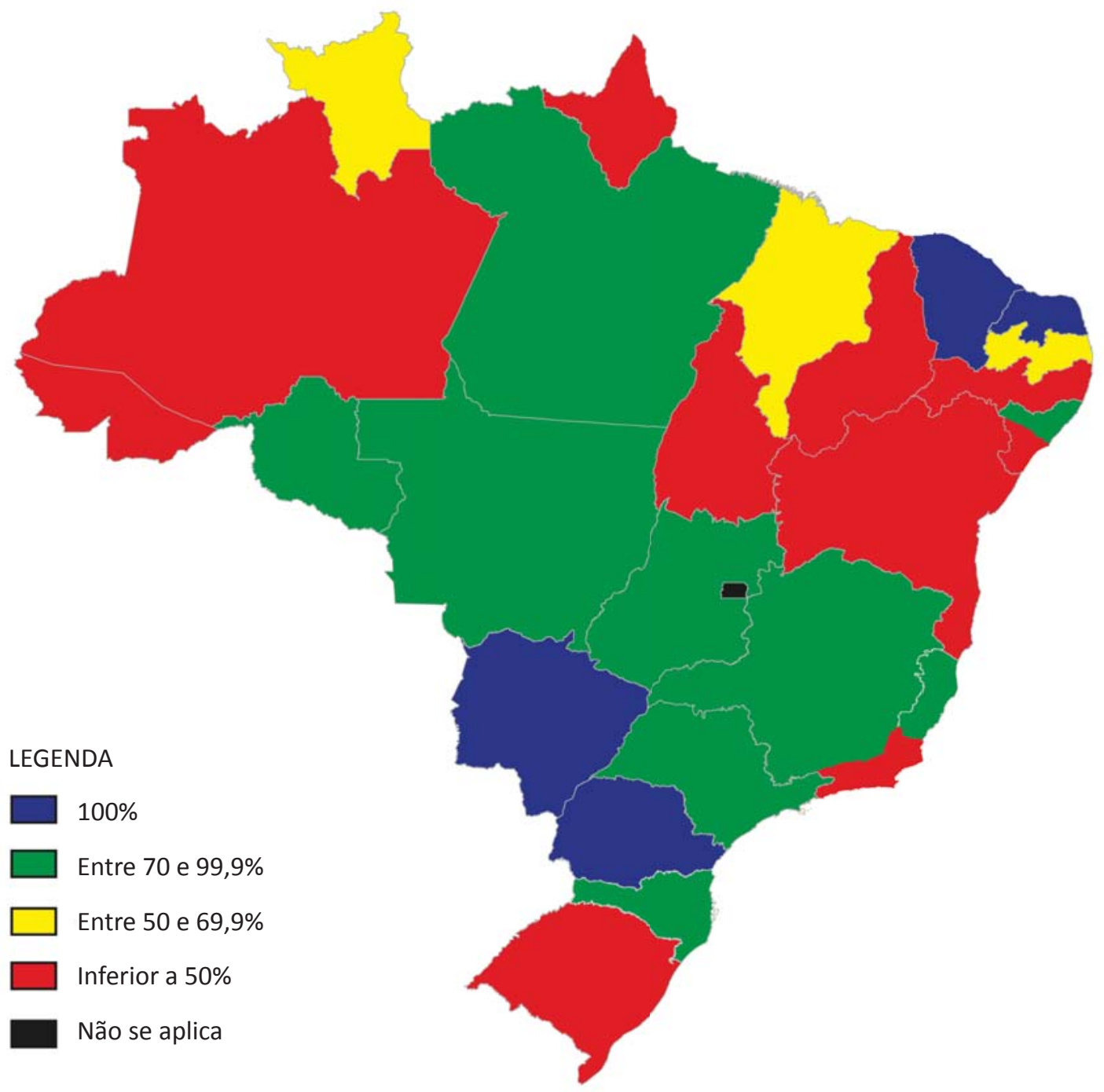

Fonte: Brasil. Ministério da Saúde, Secretaria Técnica da Comissão Intergestores Tripartite. 2010. Extraído de LIMA et al, 2011.

Ressalta-se que há estados que adotaram um ritmo aparentemente mais lento nos processos de adesão estadual e municipal. Alguns desses estados, contudo, optaram por atualizar os recortes regionais vigentes em seus Planos Diretores de Regionalização (PDR), bem como por aprofundar as negociações intergovernamentais no âmbito dos CGR, de modo a favorecer o planejamento regional e a adesão conjunta dos municípios ao Pacto nas regiões de saúde. São conduções que revelam as expectativas dos gestores em relação ao fortalecimento dos processos de regionalização, num contexto de implantação ou reconfiguração de instâncias de pactuação regional. 
Para além dos TCG propostos pelo Pacto, existem experiências de contratualização envolvendo diferentes esferas de governo no âmbito do SUS. Em Sergipe, a proposta de implantação do Pacto associa-se à celebração de um único contrato - o Contrato de Ação Pública-, que envolve todos os 72 municípios do estado, bem como o governo estadual. Este processo requereu a aprovação de uma lei estadual (Lei n 6345 de janeiro de 2008) que regulamenta e ampara o processo de contratualização entre os entes. O contrato define as responsabilidades dos municípios e do estado na prestação de serviços de promoção, proteção e recuperação da saúde, bem como o seu financiamento, e formaliza os acordos e compromissos assumidos entre os gestores, incluindo as metas relativas aos indicadores do Pacto pela Vida. Em Minas Gerais, há um amplo processo de reforma administrativa em curso no estado que inclui a formalização de contratos entre entes públicos de diferentes esferas administrativas tendo em vista a consolidação de redes regionalizadas de atenção à saúde (PESTANA e MENDES, 2004).

Recentemente publicado, o Decreto n. 7.508, de 28 de junho de 2011 (BRASIL, 2011), estabelece o Contrato Organizativo da Ação Pública da Saúde como instrumento de colaboração entre os entes federativos para a organização da rede de atenção integral à saúde em uma determinada região. Segundo o decreto, este contrato deverá conter "as responsabilidades individuais e solidárias dos entes federativos com relação às ações e serviços de saúde, os indicadores e as metas de saúde, os critérios de avaliação de desempenho, os recursos financeiros que serão disponibilizados, a forma de controle e fiscalização da sua execução e demais elementos necessários à implementação integrada das ações e serviços de saúde".

À diferença dos TCG, os contratos estabelecem um acordo entre os entes com criação de vínculos e definição de obrigações recíprocas, estando sujeitos a sanções e punições dos órgãos de controle interno e externo do Poder Executivo, em função do descumprimento por uma das partes.

Qualquer que seja o instrumento adotado para formalização dos acordos entre os entes governamentais na saúde (TCG, contratos), este requer o fortalecimento dos processos de planejamento regional e regulação nas secretarias de saúde, bem como nas instâncias regionais (incluindo os Colegiados de Gestão Regional), tendo em vista a consolidação de redes regionalizadas de atenção à saúde.

\subsection{O Sistema de Partilha de Recursos Financeiros na Saúde}

A implantação do SUS depende das condições político-institucionais das esferas municipais e estaduais, sendo a capacidade de financiamento desses governos peça fundamental para a garantia do acesso universal e do cuidado integral realizado de acordo com padrões de qualidade reconhecidos. 
No entanto, existe uma contradiçãointrínseca entre as desigualdades regionais que configuram a federação brasileira e o modelo pretendido na saúde. As desigualdades trazem enormes desafios tanto para a configuração do sistema tributário que deve prover de modo adequado aos governos os recursos requeridos pelas políticas públicas, quanto para a definição de esquemas de financiamento setorial que as compensem.

Segundo Prado (2003a, 2003b), a formatação de sistemas tributários em países federativos é uma tarefa complexa. Além dos requisitos clássicos - tributar com eqüidade e eficiência, adequar a distribuição de recursos via orçamento e executar o dispêndio visando a melhoria dos resultados alcançados - estes sistemas devem: contemplar a distribuição equilibrada de encargos (responsabilidades e funções) entre as esferas de governo; repartir de modo eficiente as competências tributárias; e elaborar um sistema adequado de partilha fiscal. Essas três variáveis são igualmente importantes para o entendimento dos diversos arranjos no federalismo fiscal, existindo estreitas relações de dependência entre elas.

Particularmente, os mecanismos de transferência intergovernamental de recursos tributários que conformam os sistemas de partilha fiscal, destinados ou não ao financiamento de atividades específicas (incluindo a saúde), atuam na correção de dois tipos desequilíbrios (WATTS, 2006):

1. os verticais, gerados pela concentração de poder de tributação em contraposição às maiores necessidades de gastos das esferas subnacionais decorrentes de processos de descentralização;

2. os horizontais, que resultam, por um lado, de capacidades diferenciadas dos governos na provisão de serviços em sistemas de tributação comparáveis e, por outro, de demandas distintas de gastos públicos em função de variações das necessidades da população.

Essa distribuição de recursos implica em relações orçamentárias entre unidades de governo de diferente (partilha vertical) ou igual esfera administrativa (partilha horizontal). Enquanto no primeiro caso o objetivo é dotar os governos de recursos compatíveis com suas atribuições legais, no segundo caso, o propósito é gerar maior homogeneidade das receitas disponíveis e do poder de gasto entre as esferas subnacionais.

Desequilíbrios verticais favoráveis à União são justificados por razões de ordem econômica e tributária, mas também de ordem política (DAIN, 1995). Por outro lado, certas assimetrias entre as unidades subnacionais são constitutivas às federações e justificam a própria origem e manutenção dos arranjos federativos (BURGESS, 1993).

No caso da saúde, a literatura indica a importância da União na condução 
do processo de implantação de sistemas de saúde nacionais e universais em países federativos (BANTING e CORBETT, 2002; FRANCE, 2002). Entre os instrumentos utilizados destacam-se a normatização, traduzida pela definição de princípios e diretrizes válidos para todo o território e as transferências financeiras federais.

Juntos tais instrumentos tendem a acomodar dois valores presentes nestas sociedades: a cidadania social, que se reflete no compromisso da oferta de um conjunto de bens e serviços para todos os cidadãos; a diversidade regional, que se expressa pela tomada de decisão descentralizada quanto ao destino final dos recursos nos espaços locorregionais.

As transferências intergovernamentais, portanto, cumprem papel fundamental e reforçam o poder central na correção dos desequilíbrios e promoção da equalização fiscal em grande número de países. Mas há de se considerar a experiência de algumas federações em que as esferas estaduais ocupam papel mais importante. Este é o caso da Alemanha, em que a partilha entre os estados (denominados laender) representam mais de 60\% das transferências intergovernamentais e permitem a equalização horizontal na federação e as transferências federais possuem caráter redistributivo apenas suplementar (MORAES, 2001)

Vários são os fatores que interferem na adoção de determinados esquemas de repartição financeira, os critérios e condicionantes utilizados, assim como os governos envolvidos nos mecanismos de transferência implantados. Em geral, quanto mais descentralizados os encargos e mais significativas as desigualdades regionais, maiores são as necessidades de implantação de mecanismos de equalização fiscal para promover o equilíbrio horizontal da receita disponível ${ }^{44}$.

Para países como Alemanha, Canadá, Austrália e, em menor proporção, Suíça, as denominadas 'transferências solidárias' são fundamentais para garantir uma diminuição das diferenças orçamentárias entre as esferas subnacionais, embora nem sempre considerem as necessidades efetivas de gasto dos governos. No Canadá, por exemplo, o principal programa de transferência intergovernamental é o Canadian Health and Social Transfer (CHST), cujo objetivo é transferir recursos da União para o custeio dos programas de saúde, educação de nível superior e assistência social. Embora o governo federal relacione de forma conceitual as transferências a certos objetivos, o programa impõe poucas condições às províncias e é, com frequência, considerado um programa de transferências incondicionais (BOOTHE, 2004)

No Brasil, a legislação da saúde estabelece que as transferências de recursos federais para estados, Distrito Federal e municípios devam ser realizadas de forma regular e automática por meio de Fundos de Saúde. O artigo 35 da Lei

44 O conceito de receita disponível inclui a arrecadação própria de tributos (impostos, taxas e contribuições), com acréscimo elou subtração das transferências intergovernamentais previstas nos sistemas de partilha fiscal. Refere-se, portanto, ao resultado final da receita orçamentária após as transferências intergovernamentais. 
Orgânica da Saúde (BRASIL, 1990a) define as variáveis a serem consideradas no cálculo dos montantes a serem transferidos: perfil demográfico da região e epidemiológico da população; características da rede de serviços de saúde; desempenho técnico, econômico e financeiro no período anterior; níveis de participação da saúde nos orçamentos municipais e estaduais; previsão de investimentos; ressarcimento do atendimento prestado a outras esferas de governo. Além disso, metade dos recursos destinados às esferas subnacionais deve ser distribuída segundo parâmetro per capita.

Ela também indica a necessidade de abertura de conta especial para o recebimento das transferências, cuja movimentação deve ser objeto de fiscalização pelo respectivo Conselho de Saúde. Ao Ministério da Saúde, cabe acompanhar, através de seu sistema de auditoria, a aplicação dos recursos, bem como adotar as medidas previstas em caso de desvios e não utilização dos recursos.

Esta Lei foi desconfigurada por 25 vetos efetuados pelo Presidente Collor, logo após sua aprovação pelo Congresso Nacional, que prejudicaram, além de outros itens, os relativos aos mecanismos de transferência de recursos federais para os governos municipais e estaduais. Assim, as transferências federais são objeto de Lei complementar — a Lei 8142 (BRASIL, 1990b) - que resgata e enfatiza seu caráter regular e automático.

A Lei 8142 estipula como único critério a ser seguido, na falta de regulamentação do artigo n.35 da Lei 8080, "o quociente de sua divisão pelo número de habitantes, independentemente de qualquer procedimento prévio". Os recursos transferidos podem ser utilizados de forma ampla pelos gestores: em investimentos na rede de serviços, na cobertura assistencial e hospitalar e nas demais ações e serviços de saúde em seus diversos níveis de complexidade. Os condicionantes para as transferências também foram dispostos nesta lei: estabelecimento dos Fundos Estaduais e Municipais e Conselhos de Saúde; elaboração de Plano de Saúde; existência de contrapartida de recursos no orçamento dos estados e municípios; e constituição de uma comissão para elaborar um Plano de Carreira, Cargos e Salários (PCCS). Além disso, há previsão de que pelo menos 70\% dos recursos transferidos sejam destinados aos municípios.

Fica claro pelos dispositivos legais que havia a intenção de propiciar à União formas para uma distribuição mais equitativa de recursos, sem comprometer o funcionamento da rede de serviços e a especialização de alguns entes governamentais como centros de referência. Em respeito à autonomia dos demais entes federativos, a utilização final dos recursos federais poderia atender a finalidades diversas da política de saúde no âmbito locorregional, estando submetida ao poder fiscalizador dos Conselhos de Saúde.

No entanto, cabe ressaltar que tanto a Lei 8080 quanto a Lei 8142 que a complementa, não explicitam os montantes a serem transferidos, nem traduzem operacionalmente a composição dos critérios para as transferências federais. A cooperação financeira dos estados aos municípios é estabelecida de modo vago 
como também não ficam claros os dispositivos a serem utilizados no caso de estabelecimento de consórcios ou outros instrumentos para formalização de acordos intergovernamentais envolvendo instâncias da mesma esfera de governo.

O contexto de restrição e insuficiência de recursos financeiros, bem como o modelo de federalismo fiscal adotado, fez crescer nos anos subsequentes as expectativas dos gestores do SUS quanto ao financiamento público da saúde no Brasil (LIMA,2007a; LIMA, 2007b). Entre outras questões, destacam-se: a garantia de fontes estáveis e de condições de financiamento e gasto adequadas nas três esferas de governo; as possibilidades de condução federal dos rumos da política por meio de incentivos financeiros e conformação de regras nacionais; a suplementação e redistribuição de recursos fiscais para estados e municípios que pudessem compensar suas dificuldades próprias de financiamento sem maiores restrições quanto a sua gestão orçamentária; o desenvolvimento de uma política de investimentos para o SUS.

Não por acaso, desde o início da década de 1990, observam-se sucessivas mudanças nas regras que informam as transferências de recursos federais para os entes subnacionais. Tais mudanças foram promovidas pela edição de portarias ministeriais que definem os mecanismos de repasse de recursos financeiros, assim como os critérios utilizados no cálculo das transferências e os condicionantes para sua distribuição e execução em nível local.

Entre o conjunto de mudanças implantadas, verificam-se (LIMA, 2007a):

1. contenção e retardamento dos mecanismos de caráter automático por meio de transferências "fundo a fundo", associado a um tipo de descentralização fortemente tutelada pelo Ministério da Saúde;

2. transformação da ideia original de repasses globais não fragmentados (tipo block grants) para mecanismos distintos de transferência segundo nível da atenção à saúde, tipo de serviço ou programa, que exigem a adesão voluntária e, em alguns casos, a contra-partida dos entes subnacionais (tipo project grants);

3. inclusão de novos critérios e condicionantes para o recebimento e aplicação dos recursos;

4. manutenção das formas de remuneração direta do Ministério da Saúde por serviços prestados e de mecanismos conveniais.

O Quadro 4 procura sistematizar as inflexões relativas aos mecanismos de financiamento federal das ações e serviços do SUS empregados no período de 1990 a 2005 (período anterior à publicação do Pacto pela Saúde). Estão explicitadas somente as formas efetivamente implantadas, tendo em vista que muitos dos dispositivos previstos nas portarias nunca chegaram a vigorar. 
Em 2005, na vigência simultânea da Norma Operacional Básica (NOB) 01/96 e da Norma Operacional de Assistência à Saúde (NOAS) 01/2002, configura-se no Brasil um modelo diversificado de transferências federais voltadas para o SUS. Neste ano, verificam-se a transferência de montantes fixos e regulares que são depositados em contas específicas dos Fundos de Saúde independente do quantitativo de ações e serviços produzidos ("mecanismos de transferência pré-produção") e recursos que variam mensalmente de acordo com a informação da produção ("mecanismos de transferência pós-produção"). 


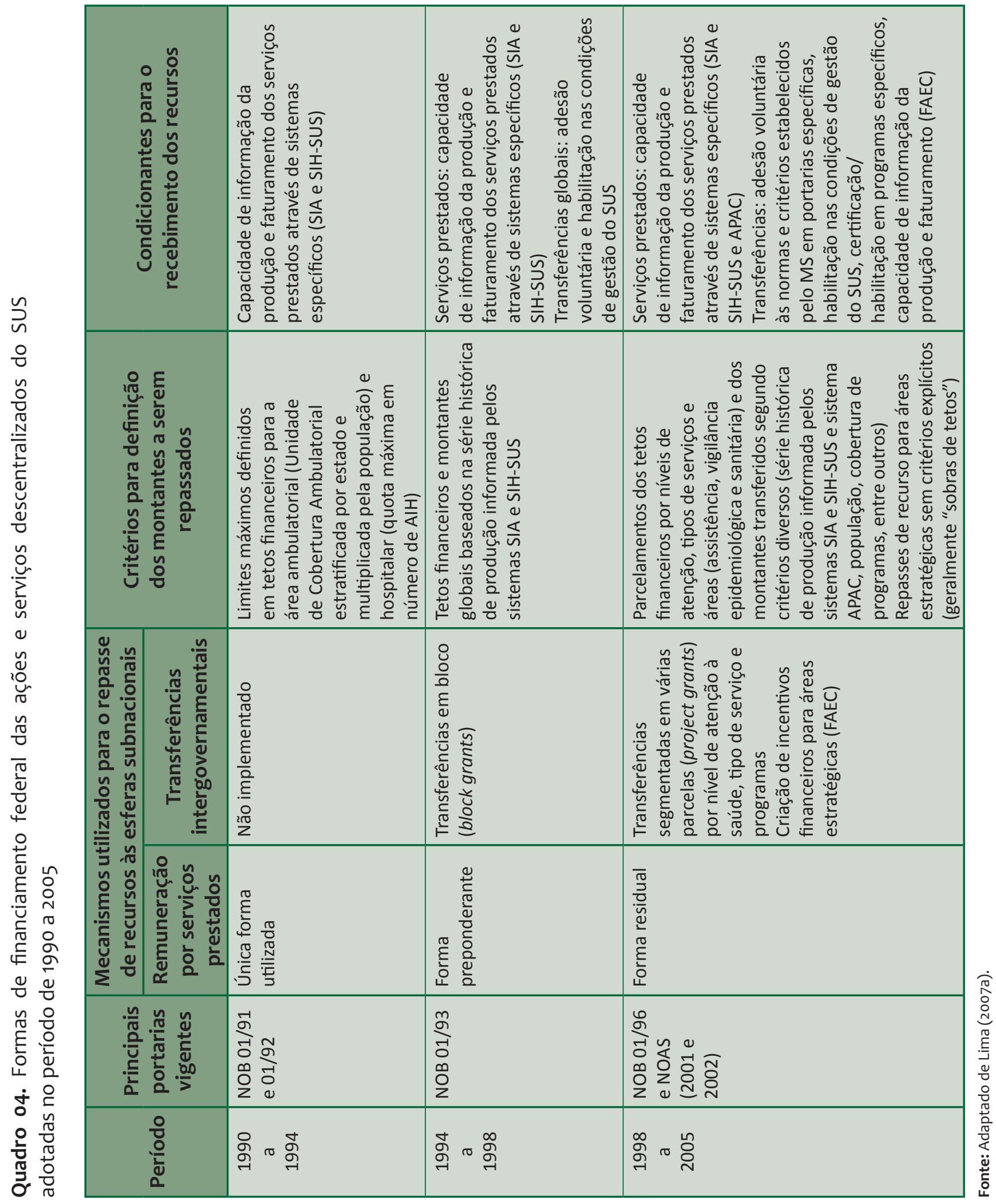


Observa-se que a ampliação dos mecanismos de transferência intergovernamental no âmbito do SUS consolida o Ministério da Saúde como o principal responsável pela redistribuição de recursos financeiros voltados para a saúde. Mas, à medida que as transferências intergovernamentais tornam-se preponderantes como formas de financiamento, e regulares para um número maior de municípios e estados, os recursos transferidos são parcelados e novos critérios e condicionantes para sua distribuição e apropriação são incorporados.

Um maior número de mecanismos utilizados pode ser observado nos programas voltados para a atenção básica financiados pelo denominado Piso de Atenção Básica (PAB) variável e nas ações estratégicas apoiadas pelo Fundo de Ações Estratégicas e Compensação (FAEC); justamente os grupos que sofrem um incremento mais expressivo de receitas na segunda metade da década de 1990 e início dos anos 2000.

Por um lado, a existência de várias modalidades para transferência de recursos, com objetivos e lógicas distintos, expressa o esforço federal de induzir e ampliar a implantação de programas prioritários em âmbito nacional. Por outro, causa elevada instabilidade nos processos orçamentários dos governos subnacionais que ficam sem parâmetros para estimar o volume de suas receitas disponíveis, sem garantir maior eficiência e efetividade no gasto. Além disso, Machado (2007) sugere que a intensa fragmentação torna complexa a gestão do conjunto das transferências pelo próprio Ministério da Saúde. Ainda que algumas modalidades tenham um sentido claro, a agregação de todas elas gera resultados antagônicos e dificulta a compreensão da direcionalidade da ação federal.

Se a prática de vinculação de recursos federais a políticas definidas nacionalmente é reconhecida como necessária na maioria das federações (PRADO, 2003a), o caso da saúde no Brasil suscita polêmica pelo elevado condicionamento sobre os gastos (ARRETCHE, 2005). Questionamentos são feitos em relação à amplitude do poder do Ministério da Saúde para distribuir recursos segundo suas prioridades versus o grau de autonomia requerida para que os gestores estaduais e municipais planejem políticas e aloquem recursos voltados para suas realidades locorregionais (CARVALHO, 2001).

Muitas destas questões foram utilizadas como justificativas para as alterações nas regras do financiamento do SUS propostas no Pacto pela Saúde. O Pacto estipula que os recursos do Ministério da Saúde destinados às ações e serviços descentralizados do SUS sejam organizados na forma de cinco blocos de financiamento (BRASIL, 2007): 1- atenção básica; 2- atenção de média e alta complexidade ambulatorial e hospitalar; 3- vigilância em saúde; 4- assistência farmacêutica; 5- gestão do SUS. Posteriormente, foi criado um sexto bloco referente aos investimentos.

Essa medida reduz o parcelamento das transferências federais e aumenta a autonomia dos entes subnacionais na gestão dos recursos, já que devem 
ser depositados em conta única e específica para cada bloco de financiamento, com exceção dos recursos relativos à assistência farmacêutica, e daqueles provenientes de acordos de empréstimos internacionais.

Em que pesem os avanços das mudanças operadas, os dispositivos que regem a distribuição de grande parte dos recursos previstos nos blocos de financiamento do Pacto pela Saúde permanecem inalterados. Cada bloco é constituído por componentes que agregam antigos e novos incentivos financeiros do Ministério da Saúde, que seguem critérios e condicionantes para sua transferência e uso definidos em portarias específicas. Assim, mesmo ganhando em termos de gestão orçamentária (os recursos depositados em conta única podem ser aplicados nas ações e serviços de saúde relacionados ao próprio bloco), a autonomia decisória dos entes subnacionais sobre o destino final de recursos permanece restrita, pois o repasse só poderá ser efetivado mediante a adesão do município ou estado ao referido programa e o compromisso da implementação das ações a que se destinam.

Cabe discutir ainda se a diversidade de critérios consolidados em cada bloco garante à União as condições necessárias para promover a redistribuição dos recursos do SUS, diminuindo as diferenças e ampliando a capacidade de gasto em saúde das esferas subnacionais, função primordial de qualquer sistema de partilha fiscal. Muitos estudos já realizados sugerem as potencialidades de algumas modalidades de transferência do SUS desenvolvidas desde a segunda metade da década de 1990 que foram mantidas no Pacto pela Saúde (tais como o Piso de Atenção Básica per capita e o PAB variável) ${ }^{45}$. Também é preciso considerar os esforços empreendidos pelo Ministério da Saúde no sentido de desconcentração regional das despesas do Fundo Nacional de Saúde (LEVI e SCATENA, 2011).

Entretanto, algumas pesquisas são mais cuidadosas ao exaltarem os resultados alcançados pelo modelo de financiamento federal consolidado no sentido de redução das desigualdades nas condições de financiamento em saúde. O estudo de Ugá et al. (2003), por exemplo, que analisa o conjunto de despesas federais e não só as transferências intergovernamentais, demonstra que o peso da oferta e da produção de serviços restringe o processo de alocação equitativa de recursos federais para o custeio do SUS ${ }^{46}$. São necessários recursos de investimentos para equilibrar a oferta de serviços existentes; a alocação de recursos adicionais de custeio que contemplem diferentes perfis demográficos, epidemiológicos e condições sócio-sanitárias e estejam orientados para as maiores necessidades de saúde; e a maior participação dos estados na correção dos desequilíbrios vigentes a fim de que se alcancem mudanças mais consistentes.

45 Entre outros, Heimann et al. (2001), Costa e Pinto (2002), Costa e Melamed (2003), Marques e Mendes (2003) e Souza R. (2002 e 2003).

46 Para discussão aprofundada sobre o tema da eqüidade na distribuição geográfica de recursos financeiros, tanto no que se refere aos conceitos como às propostas metodológicas que orientam a alocação eqüitativa na saúde, consultar os trabalhos de Porto (2002) e Porto et al. (2003). 
Nesse sentido, a pesquisa conduzida por Lima (2007a) indica que mesmo representando uma parcela expressiva de recursos nos orçamentos municipais ${ }^{47}$ e apesar de uma tendência mais equitativa das transferências federais do SUS ${ }^{48}$, a redistribuição desses recursos não foi suficiente para romper as desigualdades regionais das receitas públicas municipais, nem com a situação desfavorável dos municípios médios. Ambas são decorrentes das diferenças no volume de recursos próprios atualmente vinculados constitucionalmente à saúde pelos dispositivos da Emenda Constitucional n.29 de 2000.

Como resultado dos mecanismos de transferência federal de recursos do SUS, os municípios do Norte, Nordeste e os com população de 20 mil a 100 mil habitantes, se comparados a outros grupos:

1. possuem menores chances de ampliação de recursos próprios para a saúde como efeito da vinculação constitucional, já que a disponibilidade dessas fontes é relativamente mais baixa;

2. precisam empreender maior esforço fiscal e comprometer uma parcela mais elevada de seus orçamentos para garantirem a adequação dos recursos às suas necessidades de gasto em saúde; e

3. são os que mais dependem das transferências federais da saúde para ampliar suas receitas destinadas ao SUS e, por isso, estão mais sujeitos aos mecanismos de indução do MS.

No âmbito estadual, percebem-se importantes diferenças entre as regiões devido à capacidade de arrecadação do Imposto sobre Circulação de Mercadorias e Serviços (ICMS) e de apropriação do Fundo de Participação dos Estados (FPE), sendo particularmente crítica a situação dos estados do Nordeste (LIMA, 2007a). Em grande parte, os repasses federais regulares do SUS para os estados estão atrelados ao modelo de descentralização e partilha de funções, induzindo a frequentes disputas entre municípios e estados, especialmente no que se refere à apropriação das transferências voltadas para o custeio das ações e serviços de alta e média complexidade.

47 As transferências federais do SUS constituem atualmente uma importante fonte de receita para os municípios brasileiros. Dados consolidados a partir do Sistema de Informações de Orçamentos Públicos em Saúde (SIOPS) permitem aferir que, em 2005, estas representavam a: 1- quarta principal fonte de receita tributária, abaixo Fundo de Participação dos Municípios (FPM), da Cota-parte do Imposto sobre Circulação de Mercadorias e Serviços (ICMS) e do Fundo de Manutenção e Desenvolvimento da Educação Básica e de Valorização dos Profissionais da Educação (FUNDEB); 2- segunda principal transferência regular da União (abaixo do FPM); 3fonte de receita mais importante do que a arrecadação tributária própria em cerca de 53\% dos municípios. A importância do SUS é ainda maior nos municípios médios e situados em regiões mais carentes.

48 Sobre esse aspecto, vale ressaltar algumas iniciativas recentes de mudanças nos critérios de transferência dos recursos de atenção básica, incluindo aqueles relacionados a modalidades diferenciadas de remuneração das equipes de saúde da família e compensação das especificidades regionais, que privilegiam de modo explícito as regiões do Norte e Nordeste do país. 
A autora também sugere a fragilidade dos mecanismos de descentralização do financiamento da política de saúde adotados. Se houve avanços, esses foram temporalmente limitados e não alteraram as condições institucionais subjacentes dos municípios e estados beneficiados pelas transferências de recursos, por quatro razões principais:

1. o aumento das transferências federais não foi acompanhado de investimentos mais substantivos na rede pública de serviços. Isso é fundamental quando se quer diminuir o grau de desigualdade nas condições de oferta e de acesso à saúde associados aos vazios assistenciais ainda existentes em muitas regiões do país. Sobre este aspecto ressalta-se que a análise dos dispêndios federais da saúde indica a pouca importância dos investimentos no período de 1997 a 2004, quando se sobressaem os gastos com saneamento e as emendas parlamentares como fontes destes recursos (GADELHA, MACHADO, LIMA e BAPTISTA, 2009);

2. os critérios que regem a distribuição dos principais mecanismos de transferência federal no SUS — o Piso de Atenção Básica variável e os recursos voltados para a alta e média complexidade - estão fortemente atrelados à implantação de programas e à série histórica de produção e faturamento. No primeiro caso, os efeitos redistributivos para as regiões Norte e Nordeste se esgotam à medida que elas aderem aos programas. No segundo, somente municípios com capacidade de oferta prévia (própria ou privada credenciada) possuem maior chance de obtenção de receitas. O repasse desses recursos, portanto, se não acompanhado por investimentos na rede pública, reproduz as distorções no perfil da oferta e distribuição espacial da rede de serviços;

3. as transferências federais na saúde desconsideram as possibilidades reais de aporte de recursos e ampliação de gasto a partir das receitas próprias das esferas subnacionais e o volume de recursos transferido é insuficiente para superar as limitações orçamentárias das jurisdições menos desenvolvidas. De fato, a falta de planejamento integrado das regras que orientam as transferências nos diversos subsistemas de partilha no Brasil, assim como a fixação dos coeficientes de distribuição dos Fundos de Participação ocorrida em 1989 dificultam a correção de assimetrias ${ }^{49}$.

49 Para uma discussão acerca dos problemas e influência do modelo de partilha fiscal brasileiro no financiamento descentralizado do SUS, consultar Lima (2009). 
4. embora esforços recentes tenham sido empreendidos pelos governos estaduais, há pouca participação dos estados por meio da implantação de mecanismos automáticos de transferência aos municípios. As relações predominantes no modelo de transferência do SUS são verticais e envolvem preferencialmente o Ministério da Saúde e os municípios. Não foram suficientemente explorados os mecanismos de transferência horizontal de recursos - intermunicipais e interestaduais. A falta desses mecanismos compromete o financiamento articulado entre as três esferas de governo nos espaços regionais e dificulta a regionalização.

Aqui cabe tecer uma consideração mais geral acerca das regras relativas ao financiamento da saúde evocadas pelo Pacto: avanços mais significativos só poderão ser obtidos quando as transferências específicas da saúde forem compreendidas e planejadas como parte integrante do sistema de partilha de recursos tributários em nossa federação. Os resultados do subsistema de distribuição dos recursos da saúde, cuja finalidade precípua é o financiamento das ações e serviços descentralizados do SUS e, como tal, devem atender às necessidades da política setorial, interferem no balanço orçamentário dos governos. Por outro lado, a repartição de receitas tributárias estabelecida pela Constituição condiciona a disponibilidade da receita final destinada à saúde nas instâncias subnacionais.

\section{4 | DIRETRIZES PARA O APRIMORAMENTO DA COORDENAÇÃO FEDERATIVA NO SUS}

Neste capítulo procurou-se argumentar que as formas de articulação entre as diferentes instâncias de governo na política de saúde devem ser compreendidas à luz das condições institucionais moldadas pelo pacto federativo brasileiro e pelas peculiaridades da trajetória da descentralização e regionalização no SUS. Depreendese que mudanças mais substantivas na coordenação federativa do sistema público de saúde dependem de alterações no contexto geral subjacente a este processo.

Entre os temas que devem ser objeto de regulamentação e reformas políticas mais amplas, que informam as relações intergovernamentais no Brasil e possuem forte impacto nas políticas de saúde, dois são particularmente relevantes:

1. a legislação sobre as regras, princípios e procedimentos que disciplinam a cooperação intergovernamental;

2. a legislação fiscal e tributária no que diz respeito a gestão dos recursos públicos e ao federalismo fiscal. 
No primeiro caso, a lei pode ampliar as possibilidades de formalização das parcerias intergovernamentais na saúde, além de definir alguns procedimentos formais de diplomacia que favoreçam o entendimento e a cooperação intergovernamental. No segundo, mudanças na Lei de Responsabilidade Fiscal são necessárias para atender as necessidades de ampliação dos gastos governamentais e ampliar o caráter público do sistema de saúde. Alterações nos sistema de partilha fiscal também são fundamentais para atender aos novos requisitos de equalização impostos pelo desenvolvimento econômico e universalização das políticas sociais.

Na política de saúde, mudanças recentes evocadas pela publicação do Decreto n.7508, de 28 de junho de 2011 (BRASIL, 2011), ressaltam a necessidade do fortalecimento do enfoque territorial e da capacidade das três esferas conduzirem de modo articulado os processos de descentralização e regionalização em seu âmbito de competência.

Entretanto, é preciso considerar que o resgate do território no planejamento e na gestão da política de saúde transcende a lógica organizativa e a racionalidade setorial embutida na discussão de redes de atenção à saúde. O território (e a região) agrega a perspectiva da diversidade regional (traduzida por dinâmicas territoriais específicas), do desenvolvimento, da integração de políticas sociais e econômicas, e de articulação dos diversos campos da atenção à saúde (assistência, vigilâncias, desenvolvimento e provisão de recursos humanos, tecnologias e insumos para a saúde) que se fazem necessários para o avanço do SUS nos próximos vinte anos.

Alguns esforços podem ser empreendidos nesse sentido, tais como:

1. Alterações organizacionais, desenvolvimento e incorporação de tecnologias de informação no Ministério da Saúde e Secretarias de Saúde, que possibilitem um olhar integrado sobre o território e o reforço do planejamento regional do sistema de saúde em várias escalas territoriais.

2. Elaboração de uma pauta de negociação regional, no plano nacional e estadual, que subsidie compromissos a serem assumidos pelos gestores (atrelados ou não ao Pacto pela Saúde) no sentido de integrar a atenção à saúde aos investimentos, às ações de fomento, ao complexo industrial da saúde, às estratégias de formação e alocação de recursos humanos e à política de ciência e tecnologia no SUS.

3. Formulação de propostas que visem apoiar os processos de organização político-territorial do SUS nos estados brasileiros que levem em consideração seus condicionantes e estágios diferenciados de implementação. 
4. Valorização, atualização e diversificação das estratégias e instrumentos de negociação e pactuação intergovernamental, por meio de:

- ampliação da representatividade e do debate sobre temas de interesse regional nas instâncias federativas do SUS (ex: CIT, Conass, Conasems, CIB, Cosems e Colegiados de Gestão Regional ou Comissões Intergestores Regionais);

- ampliação da institucionalidade das instâncias federativas no plano regional (incorporação de pessoal permanente, qualificação da equipe técnica e dirigente, reforço das funções de planejamento e regulação nessas instâncias) e criação de novos arranjos em situações específicas (tais como as regiões metropolitanas, as áreas fronteiriças, as zonas limítrofes entre estados, as áreas de proteção ambiental e reservas indígenas, entre outras);

- consolidação de parcerias intergovernamentais (consórcios e contratos) a partir da configuração de planos regionais de saúde formulados e acordados nas instâncias de negociação e pactuação federativa do SUS.

Um aspecto não menos importante para o aprimoramento da coordenação federativa diz respeito ao modelo de transferência de recursos financeiros adotado no SUS. Como enfatizado, a compreensão de que os arranjos adotados na saúde são afetados e afetam o federalismo fiscal é um dos pressupostos que deve nortear qualquer proposta de mudança nos mecanismos vigentes.

Várias questões devem ser consideradas no estabelecimento de mecanismos de transferência orçamentário-financeiras entre esferas de governo. Essas questões traduzem-se como desafios técnico-metodológicos e como escolhas políticas que deverão ser enfrentadas na moldagem de um sistema de partilha que, através de mecanismos de indução, suplementação, redistribuição e equalização fiscal, tenha como principais objetivos:

- estimular a cooperação intergovernamental;

- consolidar as regiões de saúde;

- garantir um financiamento adequado do SUS em nível locorregional.

Uma importante decisão a ser tomada refere-se à proporção de recursos do orçamento do Ministério da Saúde que se destinarão ao financiamento público 
das ações e serviços descentralizados de saúde, tornando-se, portanto, transferências obrigatórias do governo federal.

Outra está relacionada à eleição de critérios que permitam extrair dos recursos financeiros transferidos pelo Ministério da Saúde o mais amplo efeito de redução das desigualdades injustas nas receitas vinculadas à saúde dos governos subnacionais. Aqui, as escolhas envolverão variáveis e parâmetros para mensuração dos montantes de recursos federais a serem transferidos, considerando-se a capacidade de autofinanciamento dos estados e municípios, as demandas diferenciadas e a distribuição das ações e serviços de saúde no território.

Além disso, é preciso estabelecer padrões adequados de oferta, cobertura e gasto público em ações e serviços de saúde (de natureza, complexidade e custos diversos) que se quer garantir por meio das transferências federais, nos diversos campos e níveis de atenção à saúde. Sugere-se que os blocos de financiamento estabelecidos pelo Pacto pela Saúde possam ser utilizados como um primeiro critério para agregação de variáveis e estimativas dos montantes a serem transferidos ${ }^{50}$. Também é preciso manter um caráter indutor atrelado aos mecanismos de transferência intergovernamental, dado o importante papel que estes possuem na expansão de políticas prioritárias que assumam uma feição pactuada entre os governos.

Esses padrões devem estar adequados às distintas realidades regionais. A adequação regional de critérios de transferência pode desempenhar um papel importante no respeito da diversidade territorial e, simultaneamente, na superação das desigualdades.

Como na Saúde, verifica-se um grau elevado de compartilhamento de funções entre os governos estaduais e municipais, e frente ao elevado número de municípios e às disparidades entre eles, é conveniente que o estabelecimento de padrões voltados para a equidade fiscal considere o orçamento integrado destas duas instâncias de governo nos limites de cada estado. No âmbito de cada estado, a distribuição de recursos federais entre os municípios e o governo estadual obedeceria aos critérios e acordos explicitados nos planos de regionalização, auxiliando, ainda, a constituição de fundos regionais tripartites (compostos pelas três esferas de governo) atrelados aos consórcios de saúde ${ }^{51}$ ou aos contratos estabelecidos entre os entes.

50 Dificilmente, no Brasil, em razão das acentuadas desigualdades regionais, poderia ser adotado um modelo de transferência único, não parcelado, do tipo block grants, tais como implantado em outros países federativos (são exemplos o Canadá e a Austrália). O padrão redistributivo das transferências federais do SUS, ainda que limitado, deve-se à manutenção da diversidade de critérios utilizados. No que se refere aos recursos voltados para a atenção básica, destacam-se o per capita simples e os incentivos diferenciados para as regiões Nordeste e Norte do país no bojo de políticas específicas. Nos níveis de média e alta complexidade, a predominância do critério de capacidade instalada e de produção de serviços para distribuição de recursos entre estados e municípios, acaba por priorizar aqueles que atuam como centros de referência no sistema de saúde.

51 A legislação recente dos consórcios públicos prevê um instrumento denominado "contrato de rateio" para que os entes consorciados possam entregar recursos financeiros ao consórcio. 
Cabe ainda a adoção de critérios para a transferência de recursos que permitam identificar, valorizar e fomentar a adoção de práticas inovadoras na gestão e no cuidado à saúde. Neste caso, faz-se necessário uma diversificação maior de estratégias e instrumentos de "premiação" que valorizem melhorias de desempenho da gestão e dos resultados atingidos. O descumprimento de uma meta acordada não necessariamente denota baixo empenho dos gestores em honrar com compromissos de melhoria das condições de saúde da população. Este pode refletir desigualdades subjacentes, bem como fragilidades das condições político-institucionais das secretarias de saúde (incluindo aqui as tecnologias e os sistemas de registro e apuração das informações em saúde disponíveis; as estruturas e processos empregados para o planejamento, o controle e avaliação das ações e serviços de saúde). Portanto, o escopo de mecanismos de premiação poderia incluir alguns indicadores de processo visando apreender a diversidade regional, valorizando o planejamento e o cumprimento de metas pelo conjunto de gestores de uma dada região, e iniciativas bem-sucedidas de cooperação e a gestão intergovernamental.

Uma terceira escolha diz respeito às formas como o sistema permitirá a realização de compensações financeiras entre estados e municípios em virtude da especialização de funções no sistema locorregional. Sobre esse aspecto, convém lembrar que existem formas de cooperação intergovernamental por meio de transferências financeiras entre instâncias do mesmo nível de governo, pouco implantadas até o momento. Estas últimas, no entanto, exigem a adoção de instrumentos de informação adequados (como o cartão SUS), que permitam identificar a origem dos pacientes atendidos e os serviços prestados.

Não menos relevante é a definição do modo como se efetuará a fiscalização, a avaliação e a prestação de contas dos governos na utilização dos recursos da saúde e a atuação dos diferentes órgãos — sistema de auditoria, Conselhos de Saúde, Comissões Intergestores, tribunais de Conta - nesse processo. Mais do que instituir penalidades ressalta-se a importância desses mecanismos para a aquisição de um padrão redistributivo dinâmico das transferências intergovernamentais no SUS. É condição de qualidade e eficiência do sistema que ele contemple revisões periódicas em função de alterações relevantes nas condições socioeconômicas e demandas por serviços, desde que os fluxos de recursos mantenham certa regularidade garantindo estabilidade ao processo de elaboração e execução orçamentária.

Por último, serão necessários novos recursos de investimento para permitir uma oferta de serviços adequada e menos desigual nas diferentes regiões do país. Esses recursos são quase uma dívida da União perante os estados e municípios que experimentaram, desde o início dos anos 2000, o planejamento integrado de suas redes de serviços, expressos nos Planos Diretores de Regionalização e Investimentos. Na sua maioria, estes planos representam uma proposta de organização de serviços já existentes pela ausência de garantias financeiras. 
As decisões acima não são simples. Elas envolvem um processo de negociação intenso entre atores políticos do Executivo, do Legislativo e da sociedade, e maior comprometimento das diferentes esferas de governo na gestão e financiamento do SUS. Por outro lado, abre uma agenda de pesquisas sobre os mecanismos de coordenação federativa na saúde, que possam gerar novos conhecimentos e apoiar o detalhamento e aprofundamento das diretrizes aqui propostas. 


\section{6 | REFERÊNCIAS BIBLIOGRÁFICAS}

ABRUCIO, F.L. Os barões da federação: os governadores e a redemocratização brasileira. São Paulo: HUCITEC/Departamento de Ciência Política da Universidade de São Paulo, 1998.

ABRUCIO, F.L. A reconstrução das funções governamentais no federalismo brasileiro. In: HOFMEISTER, W.; CARNEIRO, J. M. B. (Orgs.). Federalismo na Alemanha e no Brasil. São Paulo: Fundação Konrad Adenauer Stiftung, p. 95-105. (Série Debates, v. I, n. 22), 2001.

ABRUCIO, F.L. Reforma política e federalismo: desafios para a democratização brasileira. In: BENEVIDES, M. V.; KERCHE, F., VANNUCHI, P. (Orgs.). Reforma política e cidadania. São Paulo: Fundação Perseu Abramo, 2003.

ABRUCIO, F.L. A coordenação federativa no Brasil: a experiência do período FHC e os desafios do governo Lula. Revista de Sociologia e Política, 24: 41-67, 2005.

ABRUCIO, F.L., SAMUELS, D. A nova política dos governadores. Lua Nova, São Paulo, 40 (41):137166, 1997.

AFFONSO, R., SILVA, P.L.B. (Orgs.). A federação em perspectiva: ensaios selecionados. São Paulo: Edições Fundap, 1995.

ALBUQUERQUE, M.V.; IOZZI, F.L.; MELLO, G.A. O processo de regionalização nos estados brasileiros. In: VIANA, A.L.D. e LIMA, L.D. (Orgs.). Regionalização e relações federativas na política de saúde do Brasil. Rio de Janeiro: Contra-Capa, 2011. p.117 a 172.

ALMEIDA, M. H. T. Federalismo, democracia e governo no Brasil: ideias, hipóteses e evidências. Revista Brasileira de Informação Bibliográfica em Ciências Sociais (BIB), 51: 13-34, 2001.

ALMEIDA, M.H.T. Recentralizando a federação? Revista de Sociologia e Política, Curitiba, 24: 29-40, 2005.

ALMEIDA, M.H.T. O Estado no Brasil contemporâneo. In: MELO, C.R., SÁEZ, M.A. (Orgs.). A Democracia Brasileira: balanço e perspectivas para o século 21. Belo Horizonte: Ed. UFMG, 2007. p. 17-37.

ARRETCHE, M.T.S. Estado federativo e políticas sociais: determinantes da descentralização. Rio de Janeiro: REVAN/ São Paulo: FAPESP, 2000. 302 p.

ARRETCHE, M.T.S. Federalismo e relações intergovernamentais no Brasil: a reforma de programas sociais. Dados, 45(3): 431-458, 2002.

ARRETCHE, M.T.S. Quem taxa e quem gasta: a barganha federativa na federação brasileira. Revista de Sociologia e Política, Curitiba, v.24, p. 69-85, 2005.

ARRETCHE, M.T.S. Continuidades e descontinuidades da Federação Brasileira: de como 1988 facilitou 1995. Dados, 52 (2): 377-423, 2009.

BANTING, K.; CORBETT, S. Federalismo y políticas de atención a la salud. In: AUCLAIR, C.; CARRASCO, C.H.G. (Ed.). Federalismo y políticas de salud: descentralización y relaciones intergubernamentales desde una perspectiva comparada. Ottawa: Foro de Federaciones/ Ciudad de México: Instituto Nacional para el Federalismo y Desarrollo Municipal, 2002. 
BOOTHE, P. Tributação, gastos e compartilhamento nas federações: a evidência da Austrália e do Canadá. In: BOOTHE, P.(Ed.). Relações fiscais em países federais: quatro artigos. Ottawa: Foro de Federaciones; Ciudad de México: Instituto Nacional para el Federalismo y Desarrollo Municipal, 2004. p. 7-20.

BRANDÃO, C. Território e desenvolvimento: as múltiplas escalas entre o local e o global. Campinas: Editora da Unicamp, 2007.

BRASIL, MINISTÉRIO DE SAÚDE. Descentralização das Ações e Serviços de Saúde - A Ousadia de Fazer Cumprir a Lei. Brasília: Ministério da Saúde, 1993.

BRASIL, MINISTÉRIO DA SAÚDE. Regionalização solidária e cooperativa: orientações para sua implementação no SUS. (Série Pactos pela Saúde, v.3). Brasília: Ministério da Saúde, 2006 (c).

BRASIL, MINISTÉRIO DA SAÚDE. Colegiado de Gestão Regional na região de saúde intraestadual:orientações para organização e funcionamento. (Série Pactos pela Saúde, v.10). Brasília: Ministério da Saúde, 2009a.

BRASIL. MINISTÉRIO DA SAÚDE. GABINETE DO MINISTRO. Portaria GM/MS n.399 de 22 de fevereiro de 2006. Divulga o Pacto pela Saúde 2006 — Consolidação do SUS e aprova as Diretrizes Operacionais do Referido Pacto. Brasília: Diário Oficial da União 2006(a), 23 fev.

BRASIL. MINISTÉRIO DA SAÚDE. GABINETE DO MINISTRO. Portaria GM/MS n.699 de 30 de março de 2006. Regulamenta as diretrizes operacionais dos Pactos pela Vida e de Gestão. Brasília: Diário Oficial da União 2006 (b), 03 abr.

BRASIL. MINISTÉRIO DA SAÚDE. GABINETE DO MINISTRO. Portaria GM/MS n. 204 de 29 de janeiro de 2007. Regulamenta o financiamento e a transferência dos recursos federais para as ações e os serviços de saúde, na forma de blocos de financiamento, com o respectivo monitoramento e controle. Brasília: Diário Oficial da União 2007, 31 jan.

BRASIL. MINISTÉRIO DA SAÚDE. GABINETE DO MINISTRO. Portaria GM/MS n. 2751 de 11 de novembro de 2009. Dispõe sobre a integração dos prazos e processos de formulação dos instrumentos do Sistema de Planejamento do Sistema Único de Saúde (SUS) e do Pacto pela Saúde. Brasília: Diário Oficial da União 2009, 12 nov. 2009 (b).

BRASIL. MINISTÉRIO DA SAÚDE. GABINETE DO MINISTRO. Portaria GM/MS n.4279 de 30 de dezembro de 2010. Estabelece diretrizes para a organização da Rede de Atenção à Saúde no âmbito do Sistema Único de Saúde. Brasília: Diário Oficial da União, 2010, 30 dez.

BRASIL, MINISTÉRIO DE SAÚDE, Secretaria da Atenção à Saúde. Relações entre níveis de governo na gestão do SUS. São Paulo, 2002. Slide 9. Trabalho apresentado no Seminário Tendências e Desafios dos Sistemas de Saúde nas Américas, 2002. Disponível em: http://dtr2001.saude.gov. br/sas/ddga/RelacoesNiveisGov_arquivos/frame.htm. Acesso em: mai 2011.

BRASIL. PRESIDÊNCIA DA REPÚBLICA. Constituição da República Federativa do Brasil: promulgada em 5 de outubro de 1988. Brasília: Senado Federal, 1988.

BRASIL. PRESIDÊNCIA DA REPÚBLICA. Lei $\mathrm{n}^{\circ}$ 8142, de 28 de dezembro de 1990. Dispõe sobre a participação da comunidade na gestão do Sistema Único de Saúde - SUS e sobre as transferências intergovernamentais de recursos financeiros na área da saúde e dá outras providências. Diário Oficial da União 2000(b), 31 dez. Brasília, 1990 (b). 
BRASIL. PRESIDÊNCIA DA REPÚBLICA. Lei Orgânica da Saúde - Lei n. 8080 de 19 set. 1990. Dispõe sobre as condições para a promoção, proteção e recuperação da saúde, a organização e o funcionamento dos serviços correspondentes e dá outras providências. Diário Oficial da União 1990 (a), 20 set. Brasília, 1990.

BRASIL. PRESIDÊNCIA DA REPÚBLICA. Emenda Constitucional n. ${ }^{\circ} 29$, de 13 de setembro de 2000. Altera os artigos 34, 35, 156, 160, 167 e 198 da Constituição Federal e acrescenta artigo ao Ato das Disposições Constitucionais Transitórias, para assegurar os recursos mínimos para o financiamento das ações e serviços públicos de saúde. Diário Oficial da União 2000 (a), 14 set. Brasília, 2000.

BRASIL. PRESIDÊNCIA DA REPÚBLICA. Lei Complementar n. ${ }^{\circ} 101$ de 4 de maio de 2000. Estabelece normas de finanças públicas voltadas para a responsabilidade na gestão fiscal e dá outras providências. Diário Oficial da União 2000 (b), 05 mai. Brasília, 2000.

BRASIL. PRESIDÊNCIA DA REPÚBLICA. Lei $\mathrm{n}^{\circ}$ 11.107, de 6 de abril de 2005. Dispõe sobre as normas gerais de contratação de consórcios públicos e dá outras providências. Diário Oficial da União 2005, 07 abr. Brasília, 2005.

BRASIL. PRESIDÊNCIA DA REPÚBLICA. Decreto $n^{\circ}$ 6.017, de 17 de janeiro de 2007. Regulamenta a Lei $n^{\circ}$ 11.107, de 6 de abril de 2005, que dispõe sobre as normas gerais de contratação de consórcios públicos. Diário Oficial da União 2007, 18 jan. Brasília, 2007.

BRASIL. PRESIDÊNCIA DA REPÚBLICA Decreto $\mathrm{n}^{\circ}$ 7.508, de 28 de junho de 2011. Regulamenta a Lei $n^{\circ}$ 8.080, de 19 de setembro de 1990, para dispor sobre a organização do Sistema Único de Saúde — SUS, o planejamento da saúde, a assistência à saúde e a articulação interfederativa, e dá outras providências. Diário Oficial da União 2011, 29 jun. Brasília, 2011.

BREMAEKER, F. E. J. Evolução do quadro municipal brasileiro no período entre 1980 e 2001. Rio de Janeiro: Instituto Brasileiro de Administração Municipal, 2001. 11 p. (Série Estudos Especiais n. 20)

BURGESS, M. Federalism and federation: a reappraisal. In: BURGESS, M., GAGNON, A.G. (Orgs.). Comparative federalism and federation: competing traditions and future directions. Toronto: University of Toronto, 1993. p. 3-14.

CAMPOS, G. W. S. Efeitos paradoxais da descentralização do Sistema Único de Saúde do Brasil. In: FLEURY, Sonia. Democracia, descentralização e desenvolvimento: Brasil \& Espanha. Rio de Janeiro: Editora FGV, 2006. p. 417-442.

CARVALHO, G. A inconstitucional administração pós-constitucional do SUS através de normas operacionais. Ciência e Saúde Coletiva, Rio de Janeiro, v. 6, n. 2, p. 435-444, 2001.

CARVALHO, J. M. Federalismo y Centralización em El Império Brasileño: Historia y Argumento. In: CARMAGNANI, M. (Coord.) et al. Federalismos Latinoamericanos: México/Brasil/Argentina. México: El Colégio de México/Fondo de Cultura Econômica, 1996. p.51-80.

COSTA, N. R.; PINTO, L.F. Piso de atenção básica: mudanças na estrutura. In: NEGRI, B.; VIANA, A.L. D. (Orgs.). O SUS em dez anos de desafios. São Paulo: Sobravime; Cealag, 2002. p. 271-297.

COSTA, R.C.R. Descentralização, financiamento e regulação: a reforma do sistema público de saúde no Brasil durante a década de 1990. Revista Sociologia e Política, 18\; 49-71, 2002. 
DAIN, S. Dilemas do Estado diante da nova ordem econômica e social. In: VALLADARES, L., COELHO, M. P. (Orgs.). Governabilidade e pobreza no Brasil. Rio de Janeiro: Civilização Brasileira, 1995. p. 65-104.

DALLARI, S. G. Os Estados Brasileiros e o Direito à Saúde. São Paulo: Hucitec, 1995. 133 p.

DANIEL, C., SOMEKH, N. Gestão compartilhada, limites e possibilidades: a experiência do Grande ABC. In: FUNDAÇÃO PREFEITO FARIA LIMA (Org.). Consórcio: uma forma de cooperação intermunicipal. São Paulo: Fundação Prefeito Faria Lima/Cepam. Unidades de Políticas Públicas, 2001. p. 159-170

DOLHNIKOFF, M. O Pacto Imperial: origens do federalismo no Brasil do século XIX. São Paulo: Globo, 2005.

ELAZAR, D. J. Exploring federalism. Tuscaloosa, AL: University of Alabama, 1987. 335 p.

FLEURY, S.; OUVERNEY, A.M. Gestão de redes: a estratégia de regionalização da política de saúde. Rio de Janeiro: Editora FGV, 2007.

FRANCE, G. Federalismo fiscal: experiências internacionais e modelo para a Itália. In: NEGRI, B., VIANA, A.L.D. (Orgs.). O SUS em dez anos de desafios. São Paulo: Sobravime: Cealag, 2002. p. 65-83.

GADELHA, C. A. G., et al. Saúde e desenvolvimento: uma perspectiva territorial. In: VIANA, A. L. D.; ELIAS, P. E. M.; IBAÑEZ, N. (Orgs.). Saúde, desenvolvimento e território. São Paulo: Hucitec, 2009. p. 97-123.

GERSCHMAN, S. A democracia inconclusa: um estudo da reforma sanitária brasileira. Rio de Janeiro: Fiocruz, 1995.

GOMES, G. M., MAC DOWELL, M. C. Descentralização política, federalismo fiscal e criação de municípios: o que é mau para o econômico nem sempre é bom para o social. Brasília: IPEA, 2000. (Texto para Discussão n.706).

GOULART, F. A. A. Municipalização Veredas: caminhos do movimento municipalista de saúde no Brasil. Rio de Janeiro: Abrasco/Conasems, 1996.

GUIMARÃES, L. Arquitetura da Cooperação Intergovernamental: os Consórcios em Saúde de Mato Grosso. 2001. Dissertação (Mestrado em Saúde Pública) - Escola Nacional de Saúde Pública Sergio Arouca, Rio de Janeiro, 2001.

HALL, P.; TAYLOR, R. As três versões do neo-institucionalismo. Lua Nova, 58:193-224, 2003.

HAM, C.; HILL, M. The policy process in the modern capitalist State. Hertfordshire: Haverster Wheatsheaf, 1993.

HEIMANN, L. S. et al. Quantos Brasis?: eqüidade para alocação de recursos no SUS. São Paulo: Instituto de Saúde — SES/SP; MS; IDRC; Red; Polis, 2001. 1 CD-Rom.

INSTITUTO BRASILEIRO DE GEOGRAFIA E ESTATÍSTICA (IBGE). Perfil dos Municípios Brasileiros - Gestão Pública 2005. Rio de Janeiro: IBGE, 2006.

KUGELMAS, E., SOLA, L. Recentralização/descentralização:dinâmica do regime federativo no Brasil dos anos 90. Tempo Social, São Paulo, 11( 2): 63-83, 1999. 
KUSCHNIR, R.; CHORNY, A.H. Redes de atenção à saúde: contextualizando o debate. Ciência e Saúde Coletiva, 15 (5):2307-2316, 2010.

LEVCOVITZ, E., LIMA, L. D., MACHADO, C. V. Política de saúde nos anos 90: relações intergovernamentais e papel das normas operacionais básicas. Revista Ciência e Saúde Coletiva, 6(2): 269-291, 2001.

LEVI, M.L.; SCATENA, J.H.G. Evolução recente do financiamento do SUS e considerações sobre o processo de regionalização. In: VIANA, A.L.D.; LIMA, D.L. (Orgs.). Regionalização e relações federativas na política de saúde do Brasil. Rio de Janeiro: Contra-Capa, 2011. p. 81-113.

LIJPHART, A. Modelos de democracia: desempenho e padrões de governo em 36 países. Rio de Janeiro: Civilização Brasileira, 2003.

LIMA, A.P.G. Os Consórcios Intermunicipais de Saúde e o Sistema Único de Saúde. Cadernos de Saúde Pública, 16 (4): 985-996, 2000.

LIMA, L.D. O processo de implementação de novas estruturas gestoras no Sistema Único de Saúde: um estudo das relações intergovernamentais na CIB do RJ. 1999. Dissertação (Mestrado em Saúde Coletiva) - Instituto de Medicina Social, Universidade do Estado do Rio de Janeiro, Rio de Janeiro, 1999.

LIMA, L.D. Federalismo, relações fiscais e financiamento do Sistema Único de Saúde: a distribuição de receitas vinculadas à saúde nos orçamentos municipais e estaduais. Rio de Janeiro: Museu da República, 2007(a).

LIMA, L.D. Conexões entre o federalismo fiscal e o financiamento da política de saúde no Brasil. Ciência e Saúde Coletiva, 12(2): 511-522, 2007(b).

LIMA, L.D. Federalismo fiscal e financiamento descentralizado do SUS: balanço de uma década expandida. Revista Trabalho Educação e Saúde, 6(3): 573-597, 2009.

LIMA, L.D., et al. Pacto Federativo brasileiro e o papel do gestor estadual no SUS. In: UGÁ, M.A.; SÀ, M.C.; MARTINS, M.; BRAGA NETO, F. (Orgs.). A gestão do SUS no âmbito estadual: o caso do Rio de Janeiro. 1 ed. Rio de Janeiro: Fiocruz, 2010. p. 27-58.

LIMA, L.D., et al. Descentralização e regionalização: dinâmica e condicionantes da implantação do Pacto pela Saúde no Brasil. Ciência e Saúde Coletiva (on line), 2011. Disponível em: http:// www.cienciaesaudecoletiva.com.br/artigos/artigo_int.php?id_artigo=7249. Acesso em: jul 2011.

LOPREATO, F. L. C. O endividamento dos governos estaduais nos anos 90. Economia e Sociedade, Campinas, 15:117-158, 2000.

LUCCHESE, P.T.R. et al. A gestão compartilhada do Sistema Único de Saúde: o diálogo na Comissão Intergestores Tripartite: Projeto Descentralização On-Line 2000-2002. Rio de Janeiro: Escola de Governo; Ensp, 2003.

MACHADO, C.V. O modelo de intervenção do Ministério da Saúde nos anos 90. Cadernos de Saúde Pública, 23 (9): 2113-2126, 2007.

MACHADO, C.V., BAPTISTA, T.W.F., LIMA, L.D. O planejamento nacional da política de saúde no Brasil: estratégias e instrumentos nos anos 2000. Ciência e Saúde Coletiva, 15(5): 757-772, 2010. 
MACHADO, C. V.; LIMA, L. D., BAPTISTA, T. W. F. Configuração Institucional e o Papel dos Gestores no Sistema Único de Saúde. In: MATTA, G. C., PONTES, A. L. M. (Orgs.). Políticas de Saúde: a Organização e a Operacionalização do Sistema Único de Saúde. $1^{\circ}$ ed. Rio de Janeiro: EPSJV/ FIOCRUZ, 2007. p. 139-162.

MACHADO, C., et al. O papel das Comissões Intergestores Bipartites na regionalização. In: VIANA, A.L.D. e LIMA, L.D. (Orgs). Regionalização e relações federativas na política de saúde do Brasil. Rio de Janeiro: Contra-Capa, 2011. p.173-196.

MARQUES, R. M.; MENDES, A. Atenção básica e programa de saúde da família (PSF): novos rumos para a política de saúde e seu financiamento? Ciência e Saúde Coletiva, 8 (2): 403-415, 2003.

MÉDICI, A.C. Economia e financiamento do setor saúde no Brasil: balanços e perspectivas do processo de descentralização. São Paulo: Faculdade de Saúde Pública/USP, 1994.

MELAMED, C.; COSTA, N. R. Inovações no financiamento federal à atenção básica. Ciência e Saúde Coletiva, Rio de Janeiro, v. 8, n. 2, p. 393-401, 2003.

MELO, A.C. Crise federativa, guerra fiscal e "hobbesianismo municipal": efeitos perversos da descentralização? São Paulo em Perspectiva, 10 (3): 11-20, 1996.

MENDES, E.V. Uma agenda para a saúde. São Paulo: Editora HUCITEC, 1999.

MENDES, E.V. As redes de atenção à saúde. Belo Horizonte: ESP-MG, 2009.

MENDES, E.V. As redes de atenção à saúde. Ciência e Saúde Coletiva, 15(5): 2297-2305, 2010.

MESQUITA, A.C.S. Crise do Estado Nacional Desenvolvimentista e Ajuste Liberal: A Difícil Trajetória de Consolidação do Sistema Único de Saúde — SUS (1988/2007). 2008. Dissertação (Mestrado), Campinas: Instituto de Economia da Unicamp, 2008.

MIRANDA, A. Processo decisório em Comissões Intergestores do Sistema Único de Saúde: governabilidade resiliente, integração sistêmica (auto)regulada. Revista de Política, Planejamento e Gestão em Saúde/ABRASCO, 1(1): 117-139, 2010.

MIRANDA, A.S. Análise estratégica dos arranjos decisórios na Comissão Intergestores Tripartite do Sistema Único de Saúde. 2003. 241f. Tese (Doutorado) -Instituto de Saúde Coletiva, Universidade Federal da Bahia, Salvador, 2003.

MONTEIRO, J.C.A. Consórcio Intermunicipal de Penápolis. Divulgação em saúde para debate. Paraná: CEBES, 1989.

MORA, M. O processo de endividamento dos estados: problemas e limites à descentralização e à autonomia. 1998. Dissertação (Mestrado), Rio de Janeiro: Instituto de Economia, Universidade Federal do Rio de Janeiro, 1998.

MORA, M., VARSANO, R. Fiscal decentralization and subnational fiscal autonomy in Brazil: some facts of the nineties. Brasília: IPEA, 2001. (Texto para Discussão n.854).

MORAES, M. R. As relações intergovernamentais na República Federal da Alemanha: uma análise econômico-institucional. São Paulo: Fundação Konrad Adenauer, 2001. (Série Pesquisas; 22). 
NORONHA, J.C.; SOARES, L.T. A política de saúde no Brasil nos anos 90. Ciência e Saúde Coletiva, 6(2):445-450, 2001.

NORONHA, J.C.; LIMA L.D.; MACHADO, C.V. O Sistema Único de Saúde - SUS. In: GIOVANELLA, L.; ESCOREL, S.; LOBATO, L.V.C.; NORONHA, J.C.; CARVALHO, A.I. (Orgs.). Políticas e Sistema de Saúde no Brasil. Rio de Janeiro: Fiocruz; 2008. p. 435-472.

OLIVEIRA, F.A. Fundef e SUS: duas experiências (virtuosas?) de descentralização. In: REZENDE, F.; OLIVEIRA, F.A. (Orgs.). Descentralização e federalismo fiscal no Brasil: desafios da reforma tributária. Rio de Janeiro: Konrad Adenauer, 2003. p. 203-269.

ORGANIZACION PANAMERICANA DE LA SALUD. Redes Integradas de Servicios de Salud: conceptos, opciones de política y hoja de ruta para su implementación en las Américas. Serie La Renovación de La Atención Primaria de Salud em lás Américas. Washington DC: Organizacion Panamericana de La Salud, 2008.

PEDREIRA, R. S. Os Consórcios Intermunicipais de Saúde no Brasil: contexto, panorama e regulamentação recente. 2007. Monografia de Especialização, Rio de Janeiro: Escola Nacional de Saúde Pública Sergio Arouca, Fundação Oswaldo Cruz, 2007.

PESTANA, M.V.C.S.; MENDES, E.V. Pacto de gestão: da municipalização autárquica a regionalização cooperativa. Belo Horizonte: SES, 2004.

PIERSON, P. Politics in time: history, institutions, and social analysis. Princeton: Princeton University Press, 2004.

PIERSON, P., LEIBFRIED, S. The dynamics of social policy integration. In: LEIBFRIED, S., PIERSON, P. (Ed.). European social policy: between fragmentation and integration. Washington, D.C.: The Brookings Institution, 1995.

PORTO, S. M. Equidad y distribución geográfica de recursos financieros en los sistemas de salud. Cadernos de Saúde Pública, Rio de Janeiro, 18(4): 939-957, 2002.

PORTO, S.M., et al. Metodologia de alocação eqüitativa de recursos. Saúde em Debate, Rio de Janeiro, v. 65, p. 376-388, 2003.

PRADO, S. (Coord.), QUADROS, W., CAVALCANTI, C. E. Partilha de recursos na federação brasileira. São Paulo: FAPESP; FUNDAP/ Brasília: IPEA, 2003.

PRADO, S. Partilha de recursos e desigualdade nas federações: um enfoque metodológico. In: REZENDE, F.; OLIVEIRA, F.A. (Orgs.). Descentralização e federalismo fiscal no Brasil: desafios da reforma tributária. Rio de Janeiro: FGV: Konrad Adenauer, 2003 (a). p.273-331.

PRADO, S. Distribuição intergovernamental de recursos na federação brasileira. In: REZENDE, F., OLIVEIRA, F. A. (Orgs.). Descentralização e federalismo fiscal no Brasil: desafios da reforma tributária. Rio de Janeiro: Konrad Adenauer, 2003 (b). p. 41-125.

PRADO, S., CAVALCANTI, C. E. G. A guerra fiscal no Brasil. São Paulo: FUNDAP/ FAPESP; Brasília: IPEA, 2000.

RIBEIRO, J.M. Conselhos de Saúde, comissões intergestores e grupos de interesse no Sistema Único de Saúde (SUS). Cadernos de Saúde Pública, 13 (1):81-92, 1997. 
RIBEIRO, J.M.; COSTA, N.R. Regionalização da Assistência à Saúde no Brasil: os consórcios municipais no sistema único de saúde. Planejamento e Políticas Públicas, 22: 173-220, 2000.

RIBEIRO, P.T. A descentralização da ação governamental no Brasil dos anos noventa: desafios do ambiente político-institucional. Ciência e Saúde Coletiva, 13(3): 819-828, 2009.

SALLUM, JR., B. Crise, democratização e liberalização no Brasil. In: SALLUM JR., B.(Org.). Brasil e Argentina hoje: política e economia. Bauru, SP: EDUSC, 2004. p. 47-77.

SANTOS, L.; ANDRADE, L. O. M.. Redes interfederativas de saúde: um desafio para o SUS nos seus vinte anos. Ciência e Saúde Coletiva, 16(3): 1671-1680, 2011.

SILVA, I. F.; LABRA, M.E. As instâncias colegiadas do SUS no estado do Rio de Janeiro e o processo decisório. Cadernos de Saúde Pública, 17 (1): 22-41, 2001.

SOUZA, C. Governos e sociedades locais em contextos de desigualdades e de descentralização. Ciência e Saúde Coletiva, 7(3): 431-442, 2002.

SOUZA, C. Federalismo, desenho constitucional e instituições federativas no Brasil pós-1988. Revista de Sociologia e Política, 24: 105-121, 2005.

SOUZA, R.R. O financiamento federal do SUS: mitos e verdades. In: NEGRI, B.; VIANA, A.L.D. (Orgs.). O SUS em dez anos de desafios. São Paulo: Sobravime; Cealag, 2002. p. 411-437.

SOUZA, R.R. Redução das desigualdades regionais na alocação dos recursos federais para a saúde. Ciência e Saúde Coletiva. Rio de Janeiro, 8(2): 449-460, 2003.

STEPAN, A. Para uma nova análise comparativa do federalismo e da democracia: federações que restringem ou ampliam o poder do demos. Dados, 42 (2): 197-251, 1999.

THELEN, K; STEINMO, S. Historical institutionalism in comparative politics. In: THELEN, K; STEINMO, S.; LONGSTRETH, F. (Orgs.). Structuring Politics: historical institutionalism en comparative analysis. Cambridge: Cambridge University Press, 1992, p.1-32.

UGÁ, M.A., et al. Descentralização e alocação de recursos no âmbito do Sistema Único de Saúde (SUS). Ciência e Saúde Coletiva, Rio de Janeiro, 8(2): 417-437, 2003.

VARSANO, R. A evolução do sistema tributário brasileiro ao longo do século: anotações e reflexões para futuras reformas. Brasília: IPEA, 1996. (Texto para Discussão n.405).

VIANA, A.L.D. Sistema e descentralização: a política de saúde no estado de São Paulo nos anos 80. Tese (Doutorado), Campinas: Instituto de Economia da Universidade Estadual de Campinas, 1994

VIANA, A.L.D., LIMA, L.D., OLIVEIRA, R.G. Descentralização e federalismo: a política de saúde em novo contexto — lições do caso brasileiro. Ciência e Saúde Coletiva, 7(3): 493-507, 2002.

VIANA, A. L. D. et al. Sistema de saúde universal e território: desafios de uma política regional para a Amazônia Legal. Cadernos de Saúde Pública, Rio de Janeiro, 23 (Suppl.2): S117-S131, 2007.

VIANA, A.L.D. et al. Novas perspectivas para a regionalização da saúde. São Paulo em Perspectiva, 22 (1): 92-106, 2008. 
VIANA, A.L.D., MACHADO, C.V. Descentralização e coordenação federativa: a experiência brasileira na saúde. Ciência e Saúde Coletiva, 14(3): 807-817, 2009.

VIANA, A.L.D., LIMA, L.D., FERREIRA, M.P. Condicionantes estruturais da regionalização na saúde: tipologia dos Colegiados de Gestão Regional. Ciência e Saúde Coletiva, 15(5): 2317-2326, 2010.

VIANA, A.L.D.; LIMA, L.D. (Orgs.). Regionalização e relações federativas na política de saúde do Brasil. Rio de Janeiro: Contra-Capa, 2011.

WATTS, R. L. Comparing federal systems in the 1990s. Ontario: Institute of Intergovernmental Relations, 1996. 